\title{
Influence of Fine Recycled Concrete Powder on the Compressive Strength of Self-Compacting Concrete (SCC) Using Artificial Neural Network
}

\author{
Sara Boudali ${ }^{1, *} *$, Bahira Abdulsalam ${ }^{2}$, Amir Hossein Rafiean ${ }^{3} \oplus$, Sébastien Poncet ${ }^{4}{ }^{\oplus}$, Ahmed Soliman $^{5}$ \\ and Adel ElSafty ${ }^{6, *}$ \\ 1 Mechanical Engineering Department, Faculty of Engineering, Université de Sherbrooke and Groupe ABS, \\ Sherbrooke, QC J1L 2G7, Canada \\ 2 CIISolutions Composites Infrastructure Innovation Solutions Corp., Toronto, ON M4H1L6, Canada; \\ bahira.abdulsalam@compositeinfrastructure.com \\ 3 Department of Soil and Foundation Engineering, Civil Engineering Faculty, Semnan University, \\ Semnan 35196, Iran; a.h.rafiean@semnan.ac.ir \\ 4 Mechanical Engineering Department, Faculty of Engineering, Université de Sherbrooke, \\ Sherbrooke, QC J1K 2R1, Canada; Sebastien.Poncet@USherbrooke.ca \\ 5 Building, Civil, and Environmental Engineering, Concordia University, Montréal, QC H3G 1M8, Canada; \\ ahmed.soliman@concordia.ca \\ 6 School of Engineering, Civil Engineering, University of North Florida, Jacksonville, FL 32224, USA \\ * Correspondence: sara.boudali@Usherbrooke.ca (S.B.); adel.el-safty@unf.edu (A.E.); \\ Tel.: +1-819-919-0483 (S.B.); +1-904-620-1398 (A.E.)
}

Citation: Boudali, S.; Abdulsalam, B. Rafiean, A.H.; Poncet, S.; Soliman, A.; ElSafty, A. Influence of Fine Recycled Concrete Powder on the Compressive Strength of Self-Compacting Concrete (SCC) Using Artificial Neural

Network. Sustainability 2021, 13, 3111 https://doi.org/10.3390/su13063111

Academic Editors: Francesco Nocera, Rosa Giuseppina Caponetto,

Giada Giuffrida and

Maurizio Detommaso

Received: 27 January 2021

Accepted: 2 March 2021

Published: 12 March 2021

Publisher's Note: MDPI stays neutral with regard to jurisdictional claims in published maps and institutional affiliations.

Copyright: (c) 2021 by the authors. Licensee MDPI, Basel, Switzerland. This article is an open access article distributed under the terms and conditions of the Creative Commons Attribution (CC BY) license (https:// creativecommons.org/licenses/by/ $4.0 /)$.
Abstract: This paper aims to investigate the effect of fine recycled concrete powder (FRCP) on the strength of self-compacting concrete (SCC). For this purpose, a numerical artificial neural network (ANN) model was developed for strength prediction of SCC incorporating FRCP. At first, 240 experimental data sets were selected from the literature to develop the model. Approximately $60 \%$ of the database was used for training, 20\% for testing, and the remaining 20\% for the validation step. Model inputs included binder content, water/binder ratio, recycled concrete aggregates' (RCA) content, percentage of supplementary cementitious materials (fly ash), amount of FRCP, and curing time. The model provided reliable results with mean square error (MSE) and regression values of 0.01 and 0.97 , respectively. Additionally, to further validate the model, four experimental recycled self-compacting concrete (RSCC) samples were tested experimentally, and their properties were used as unseen data to the model. The results showed that the developed model can predict the compressive strength of RSCC with high accuracy.

Keywords: artificial neural network; self-compacting concrete; compressive strength; fine recycled concrete powder; fly ash

\section{Introduction}

Concrete is the most used material worldwide and its production has drastically increased during the last decades. Over the past years, this situation has been thoroughly noted in the construction section and initiatives have been made to change what is known as conventional practice in many examples, to search for ways to improve the construction materials performance and lower the impacts, and to produce environmentally friendly materials [1,2]. In recent years, some researchers have tried to evaluate the potential of using recycled concrete aggregates (RCA) as a replacement for natural aggregates (NA) in the concrete $[3,4]$. Self-compacting concrete (SCC), as one of the most significant advances in the concrete industry, exhibits a better performance than that of conventional concrete [5]. This may be attributed to the association of supplementary cementitious materials (SCM) and filler materials that are considered at nuclear sites and to refine the porosity of the 
cement paste and reduce permeability. In fact, filler materials are commonly used as additives in SCC to enhance strength and long-term properties [6,7]. Recycled aggregates have been successfully used and their performance was extensively investigated by several researchers to develop self-compacting concrete [8-10].

Efforts have been made to develop an efficient numerical or analytical model to predict concrete compressive strength as one of the critical parameters of SCC. In the literature, quite a few linear and nonlinear regression equations for prediction of compressive strength can be found [11,12]. The majority of these soft computing techniques have rarely been used beyond classic problems. Some developed models depended on Feret's law and Bolomey's equation [13], to predict the 28-days cured-compressive strength without accounting for any strength gain beyond 28 days $[14,15]$. Alternatively, other sophisticated models have applied soft computing techniques such as function optimization or approximation by genetic algorithms [11] or neural networks [12,16,17]. Among these techniques, artificial neural networks (ANN) became quite popular by many researchers to estimate the performance of conventional concrete [16-18], the performance of recycled aggregate concrete [3,17], and the performance of high-performance concrete [19,20]. Also, few studies have been done on self-compacting concrete incorporating recycled aggregates [21-23]. Lee et al. (2009) proposed a new methodology based mainly on an artificial neural network as a predictive tool to optimize the material properties of an optimum concrete mixture [24]. The computational power of ANN comes from its ability to learn straight from examples, find relationships between input and output parameters, and tolerate relatively imprecise or incomplete tasks, and approximate results, and be even less vulnerable to outliers $[18,25]$. To the best of the authors' knowledge, there is very little research in literature and lack of a model that predicts SCC compressive strength produced with the combination of RCA and FRCP. Simultaneously, Boudali et al. (2016) had experimentally proven the significant role of FRCP while producing sustainable self-compacting concrete. An addition of $40 \%$ of fine recycled concrete improves the strength development of SCC and self-compacting sand concrete [26]. The potential of using FRCP in producing sustainable self-compacted concrete has not been addressed enough in the literature. This study aimed at evaluating the feasibility of using the ANN method for the prediction of the compressive behavior of recycled self-compacting concrete (RSCC). The model developed in this study was designed using MATLAB neural network toolbox functions. In addition to the validation of the present model, new experiments were designed to evaluate the accuracy of the designed ANN model by a separate, unseen experimental database. Then, a parametric study was conducted to evaluate the effect of different inputs, with different percentages, on the compressive strength of RSCC.

\section{Neural Network Approach}

A neural network model was developed for this paper. The model was developed based on the experimental work conducted by the authors. The model incorporated also several experimental results from the literature used for analysis and verification. The following explains the basic principles used to build the ANN model and the details about the experimental data sets.

\subsection{Basic Principles}

Similar to the biological brain, ANN processes, and information from input data [27], the neural network modeling can classify data, recognize the pattern, find approximation function, generalize, and simulate complex operations. Such an approach is specifically suitable to predict the characteristics of complicated mixtures [28]. The structure of the ANN model could have multiple, parallel layers of nonlinear and linear processing segments, called neurons. These multiple, parallel layers include the input layer, hidden layers, and the output layer. Each layer is comprised of sets of parallel nerves [29].

Experimental data $\left(\mathrm{x}_{\mathrm{i}}\right)$ is introduced in the input layer. Then, it is adjusted by parameter connection weights $\left(\mathrm{w}_{\mathrm{ij}}\right)$ and biases $(\mathrm{b})$, as weights are the links between neurons and 
layers. Adjusted inputs go through a summation process for formation of a single input $\left(\mathrm{I}_{\mathrm{j}}\right)$ (Equation (1)) [30]:

$$
\mathrm{I}_{\mathrm{j}}=\sum_{\mathrm{i}=1}^{\mathrm{n}} \mathrm{w}_{\mathrm{ij}} \mathrm{x}_{\mathrm{i}}+\mathrm{b}
$$

After that, an activation function $\mathrm{f}(\mathrm{x})$ is applied to the single input to create an output value of the processing element over hidden layers [30]. The difference between network outputs and satisfied targets represents the error value, which is propagated back to the network through a learning algorithm. This back-propagation network could be considered as the most popular learning/training algorithm since it performs better for predicting multiple targets compared to complex and multilayer networks [28,31]. This algorithm updates the network weights and biases, which allow the model to converge rapidly. Through this training process, ANN synthesizes and memorizes correlations between inputs and outputs. Hence, sufficient and representative data are a must during the training process to permit the network to diagnose the basic structure of the information involved. When the model is well trained, it could have the ability to predict targets for any unseen input set of data within the range of the training data with a satisfying degree of accuracy [29]. Extensive sensitivity studies are performed on various networks using a trial-and-error method to evaluate their performance [32].

\subsection{Collected Experimental Data Set}

A total of 240 data sets have been collected in the literature from previous experimental works on the compressive strength of RSCC. All collected data were normalized based on the compressive strength results for control specimens made with natural aggregate at the same testing age. In addition, shape correction factors for the collected data were applied to eliminate specimen shape effects on the achieved strength following the Eurocode 2 [33] and recommendations from a previous study [34]. The data sets are presented in Table 1 and Appendix A. These data were divided into three parts for designing the model as follows: training $(60 \%)$, testing $(20 \%)$, and validation $(20 \%)$. This division helped the model to show a good generalization capability [35]. The training set data were used to train the NN models, the entire validation data were used to stop the training process, and all test data were used to assess the performance of the mode after completion of the training process.

Table 1. Statistical characteristics of the experimental database.

\begin{tabular}{|c|c|c|c|c|c|}
\hline & Parameters (Unit) & Min & Max & Mean & Standard Deviation \\
\hline \multirow{10}{*}{ Inputs } & Binder content $(\mathrm{B})\left(\mathrm{kg} / \mathrm{m}^{3}\right)$ & 208 & 460 & 363.22 & 72.33 \\
\hline & Water/binder ratio $(\mathrm{W} / \mathrm{B})$ & 0.4 & 0.65 & 0.49 & 0.08 \\
\hline & Natural aggregates (NA) $\left(\mathrm{kg} / \mathrm{m}^{3}\right)$ & 0 & 1290 & 504.89 & 454.11 \\
\hline & Recycled concrete aggregates (RCA) $\left(\mathrm{kg} / \mathrm{m}^{3}\right)$ & 0 & 1215 & 396.78 & 398.34 \\
\hline & Natural pozzolana (NP) $\left(\mathrm{kg} / \mathrm{m}^{3}\right)$ & 0 & 140 & 7 & 30.51 \\
\hline & Fly ash $(\mathrm{FA})\left(\mathrm{kg} / \mathrm{m}^{3}\right)$ & 0 & 185 & 30.12 & 61.23 \\
\hline & Fine recycled concrete powder $(\mathrm{FRCP})\left(\mathrm{kg} / \mathrm{m}^{3}\right)$ & 0 & 140 & 5.83 & 27.98 \\
\hline & Natural sand (NS) $\left(\mathrm{kg} / \mathrm{m}^{3}\right)$ & 0 & 1050 & 600.03 & 230.25 \\
\hline & Recycled sand (RS) $\left(\mathrm{kg} / \mathrm{m}^{3}\right)$ & 0 & 1050 & 90.1 & 218.85 \\
\hline & Curing time (days) & 3 & 180 & 35.04 & 38.61 \\
\hline Output & Compressive strength of RSCC (MPa) & 12 & 65 & 37.81 & 12.22 \\
\hline
\end{tabular}


For making data consistent with the tangent sigmoid transfer function limits in both layers, the data were normalized between -1 and +1 using the following equation (Equation (2)):

$$
X_{n}=\left(1-(-1) \frac{X-X_{\min }}{X_{\max }-X_{\min }}\right)-1
$$

where $X_{\min }, X_{\max }$, and $X_{n}$ are the minimum, maximum, and the normalized value of the $X$ data sample, respectively.

\subsection{Proposed ANN Model}

Ten input parameters were chosen based on their demonstrated effect on the compressive strength, namely, the binder content $(\mathrm{B})$, water/binder (W/B) ratio, natural aggregates (NA), recycled concrete aggregates (RCA), natural pozzolana (NP), fly ash (FA), fine recycled concrete powder (FRCP), natural sand (NS), recycled sand (RS), and time of curing (T). The target parameter was the compressive strength of RSCC at different curing ages.

The appropriate architecture of the proposed ANN model is described in Figure 1. The optimal values of the neural network parameters and the description of input parameters are given in Tables 2 and 3, respectively.

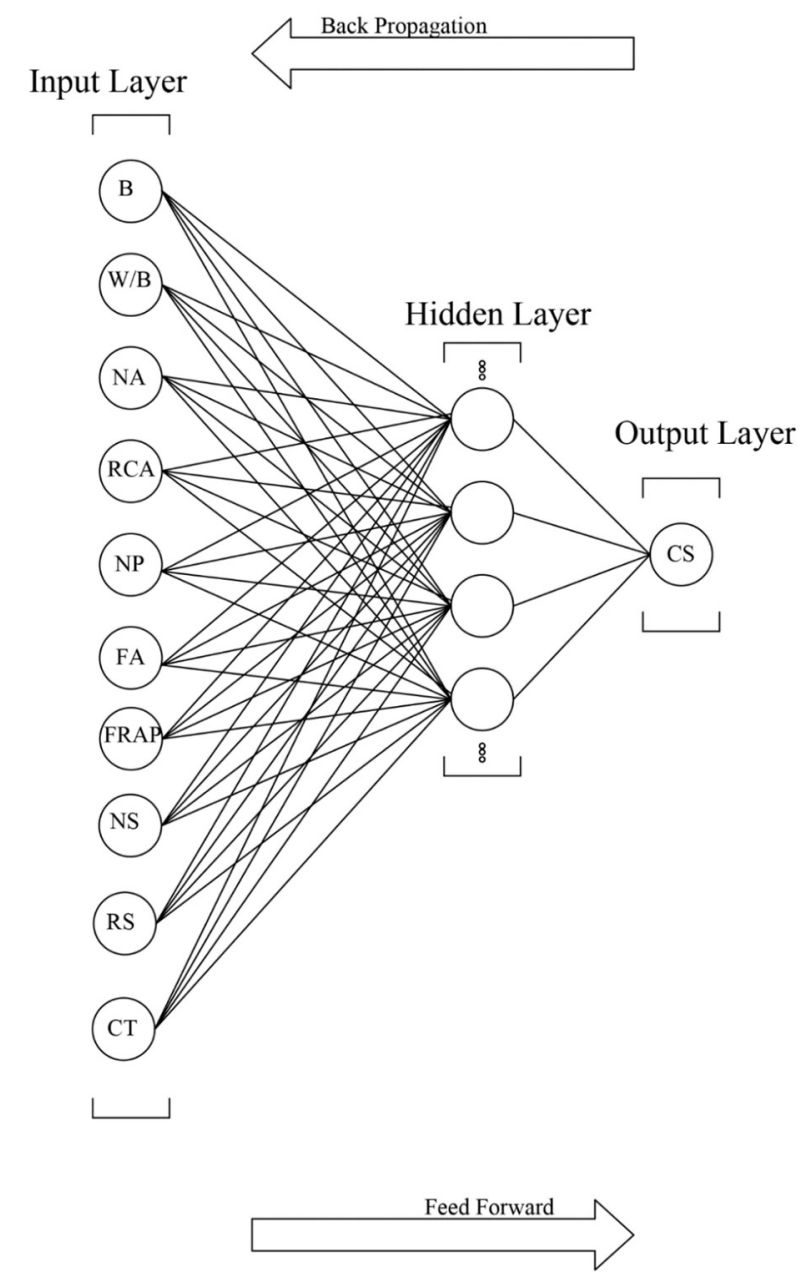

Figure 1. The architecture of artificial neural network model. 
Table 2. Values of the neural network parameters used in the ANN model.

\begin{tabular}{ll}
\hline \multicolumn{1}{c}{ Parameters } & Values \\
\hline Number of input layer units & 10 \\
\hline Number of hidden layers & 1 \\
\hline Number of hidden layer units & 10 \\
\hline Number of output layer units & 1 \\
\hline Learning rate & 0.01 \\
\hline Performance goal & $10^{-5}$ \\
\hline
\end{tabular}

Table 3. List of the input parameters.

\begin{tabular}{|c|c|}
\hline Parameter & Description \\
\hline $\mathrm{B}\left(\mathrm{kg} / \mathrm{m}^{3}\right)$ & Binder Content \\
\hline $\mathrm{W} / \mathrm{B}$ & Water/binder Ratio \\
\hline $\mathrm{NA}\left(\mathrm{kg} / \mathrm{m}^{3}\right)$ & Natural Aggregate \\
\hline $\operatorname{RCA}\left(\mathrm{kg} / \mathrm{m}^{3}\right)$ & Recycled Concrete Aggregates \\
\hline $\mathrm{NP}\left(\mathrm{kg} / \mathrm{m}^{3}\right)$ & Natural Pozzolana \\
\hline $\mathrm{FA}\left(\mathrm{kg} / \mathrm{m}^{3}\right)$ & Fly Ash \\
\hline $\operatorname{FRCP}\left(\mathrm{kg} / \mathrm{m}^{3}\right)$ & Fine Recycled Aggregate Powder \\
\hline $\mathrm{NS}\left(\mathrm{kg} / \mathrm{m}^{3}\right)$ & Natural Sand \\
\hline $\mathrm{RS}\left(\mathrm{kg} / \mathrm{m}^{3}\right)$ & Recycled Sand \\
\hline CT (days) & Curing Time \\
\hline
\end{tabular}

The performance of the best network is evaluated by extensive sensitivity studies performed on various networks using a trial-and-error method. No specific theory has been established for computing the suitable number of neurons in hidden layers and it can be calculated by the following equation (Equation (3)):

$$
\mathrm{n}=\sqrt{\mathrm{n}_{\mathrm{i}}+\mathrm{n}_{0}}+\mathrm{a}
$$

where $n$ is the number of neurons of the hidden layer, $n_{i}$ is the number of neurons of the input layer, $\mathrm{n} 0$ is the number of the neurons of the output layer, and a is a fixed amount, which ranges between 0 and 10 . Based on this formula, the number of neurons of hidden layers ranged from 3 to 13 . After so many trials, the highest regression value and the least model error were achieved by 10 neurons. Figure 2 illustrates step by step the flowchart used to select the best ANN model.

The model was designed using MATLAB neural network toolbox functions. For all the networks, the Levenberg-Marquardt algorithm was used to train the network with the log-sigmoid transfer function between the input and hidden layers and the linear transfer function between the second and output layers. This is recognized to be the fastest approach for training networks of moderate size [36]. 


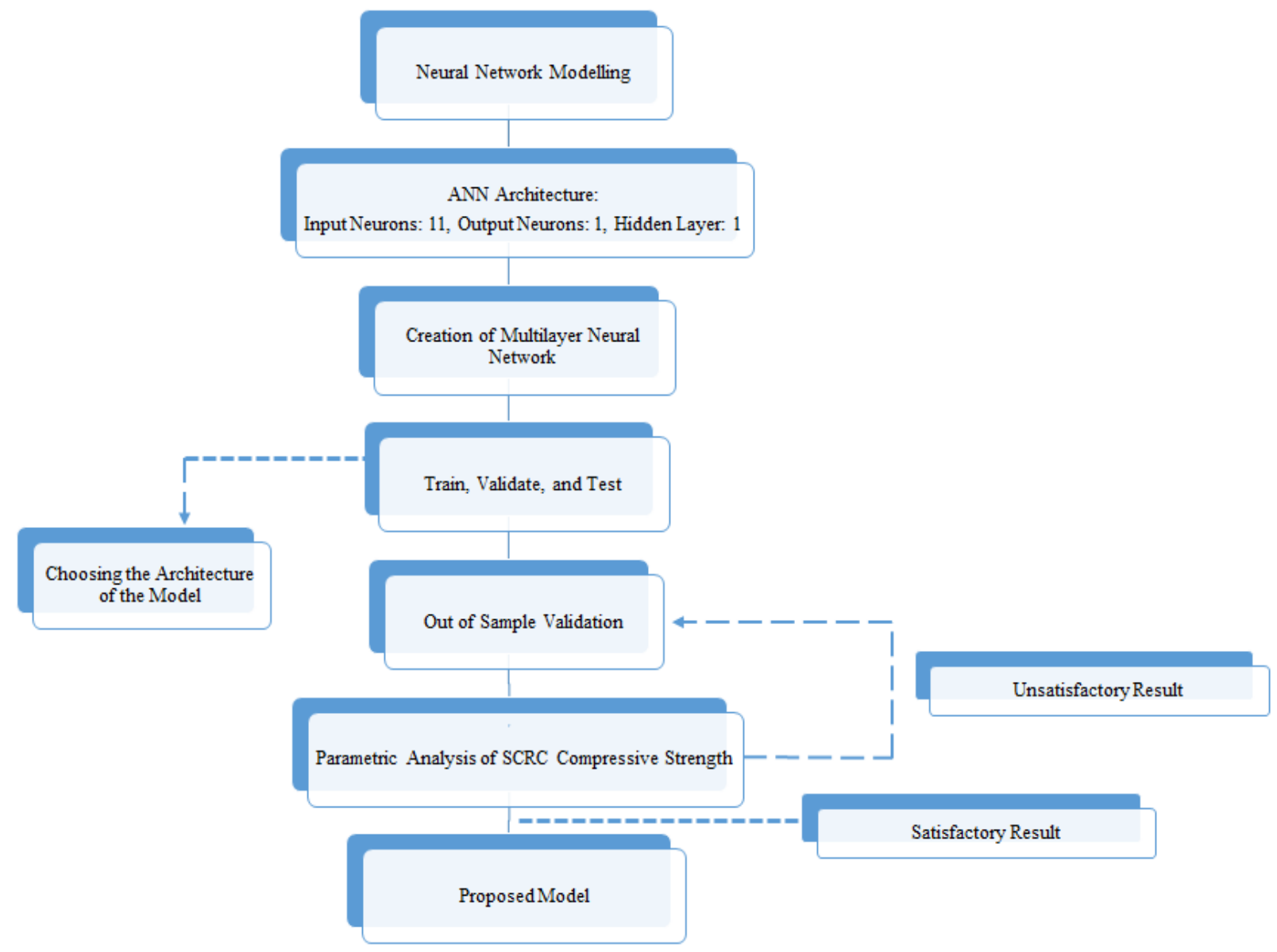

Figure 2. Flow chart used to optimize the neural network model.

\section{Results and Discussion}

\subsection{Model Performance}

The performance of any ANN model relies on the success of the training process. A well-designed, trained model should provide accurate output results as prediction, not only for input data used in the training process but also for new experimental data unfamiliar to the designed network within the same range of the training data sets. Additionally, perfect ANN models usually have only slight differences between their validation and testing errors [27]. For this purpose, five essential parameters were chosen to examine the designed model performance and its reliability, including mean square error (MSE), root mean square error (RMSE), mean absolute error (MAE), normalized mean absolute error (NMAE), and linear correlation coefficient (R). Equations (4)-(8) present the formulation for each parameter, and their values are given in Table 4 .

$$
\begin{aligned}
M S E & =\frac{1}{n} \sum_{i=1}^{n}\left(C S_{(\text {model })}-C S_{(\text {actual })}\right)^{2} \\
R M S E & =\sqrt{\frac{1}{n} \sum_{i=1}^{n}\left(C S_{(\text {model })}-C S_{(\text {actual })}\right)^{2}} \\
M A E & =\frac{1}{n} \sum_{i=1}^{n}\left|C S_{(\text {model })}-C S_{(\text {actual })}\right|
\end{aligned}
$$




$$
\begin{array}{r}
N M A E=\frac{\frac{1}{n} \sum_{i=1}^{n}\left|C S_{(\text {model })}-S C_{(\text {actual })}\right|}{C S_{\max (\text { actual })}-C S_{\min (\text { actual })}} \\
R^{2}=1-\frac{\sum_{i=1}^{n}\left(C S_{(\text {actual })}-C S_{(\text {model })}\right)^{2}}{\sum_{i=1}^{n}\left(C S_{(\text {actual })}-\overline{C S}_{(\text {actual })}\right)^{2}}
\end{array}
$$

where $C S_{a c t u a l}$ is the experimental value of compressive strength and $C S_{\text {model }}$ is its predicted value by the ANN model.

Table 4. Performance of the designed ANN model.

\begin{tabular}{ccccccc}
\hline Evaluation Parameters & $\mathbf{R}$ & $\mathbf{R}^{\mathbf{2}}$ & MSE & RMSE & MAE & NMAE \\
\hline Training & 0.97 & 0.93 & 0.01 & 0.1 & 0.043 & 2.49 \\
\hline Testing & 0.96 & 0.92 & 0.01 & 0.1 & 0.066 & 4.61 \\
\hline
\end{tabular}

$\mathrm{R}$ values greater than 0.8 showed a good connection between the actual and the modeled values [37]. $R$ values for training and testing the ANN model were 0.97 and 0.96 , respectively. Figure 3 illustrates the experimental against normalized compressive strength.

Results indicated that the designed ANN model could be a desirable approach for predicting the compressive strength of RSCC. As shown in Figure 4, the experimental and predicted compressive strength values were very close to each other.

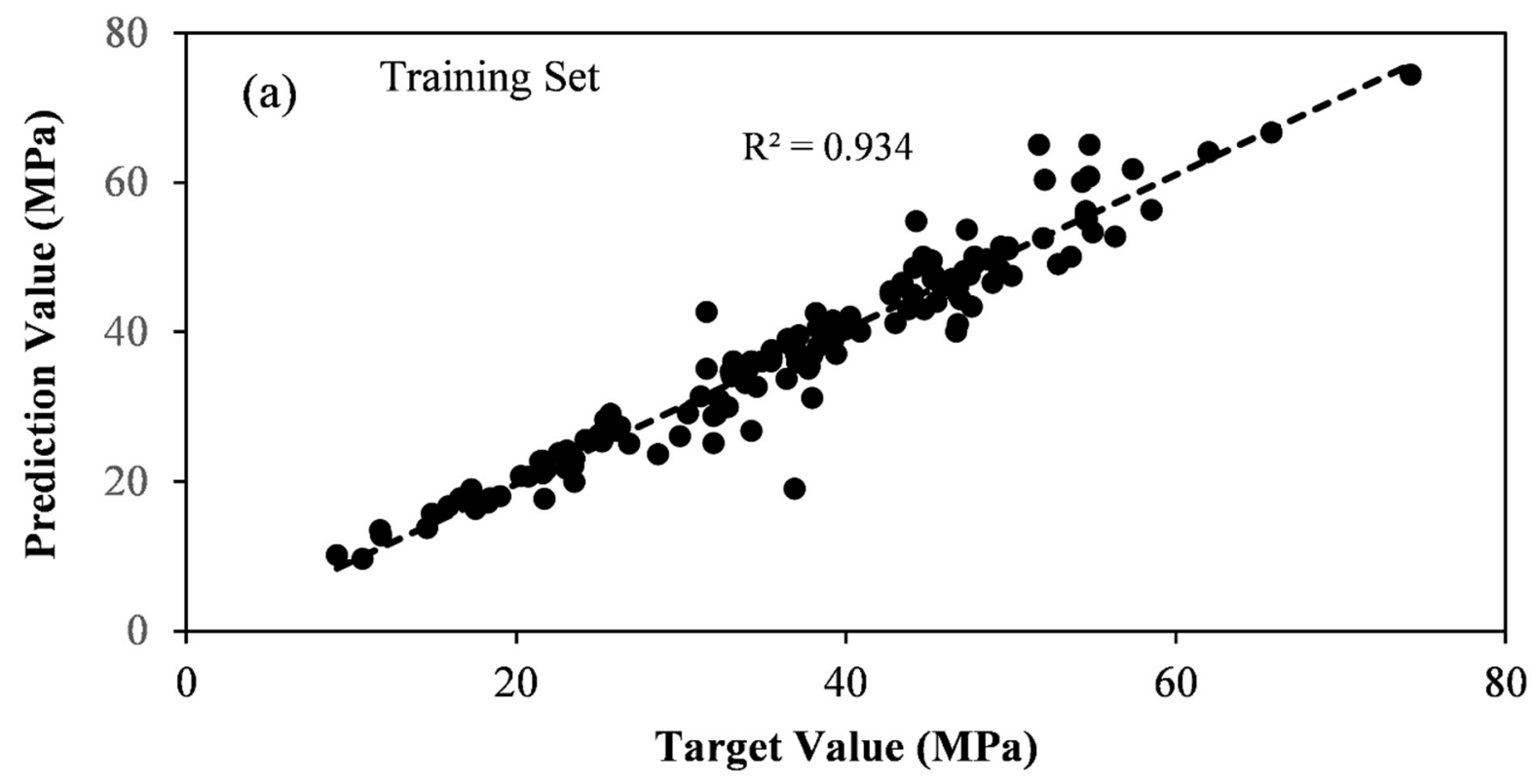

Figure 3. Cont. 

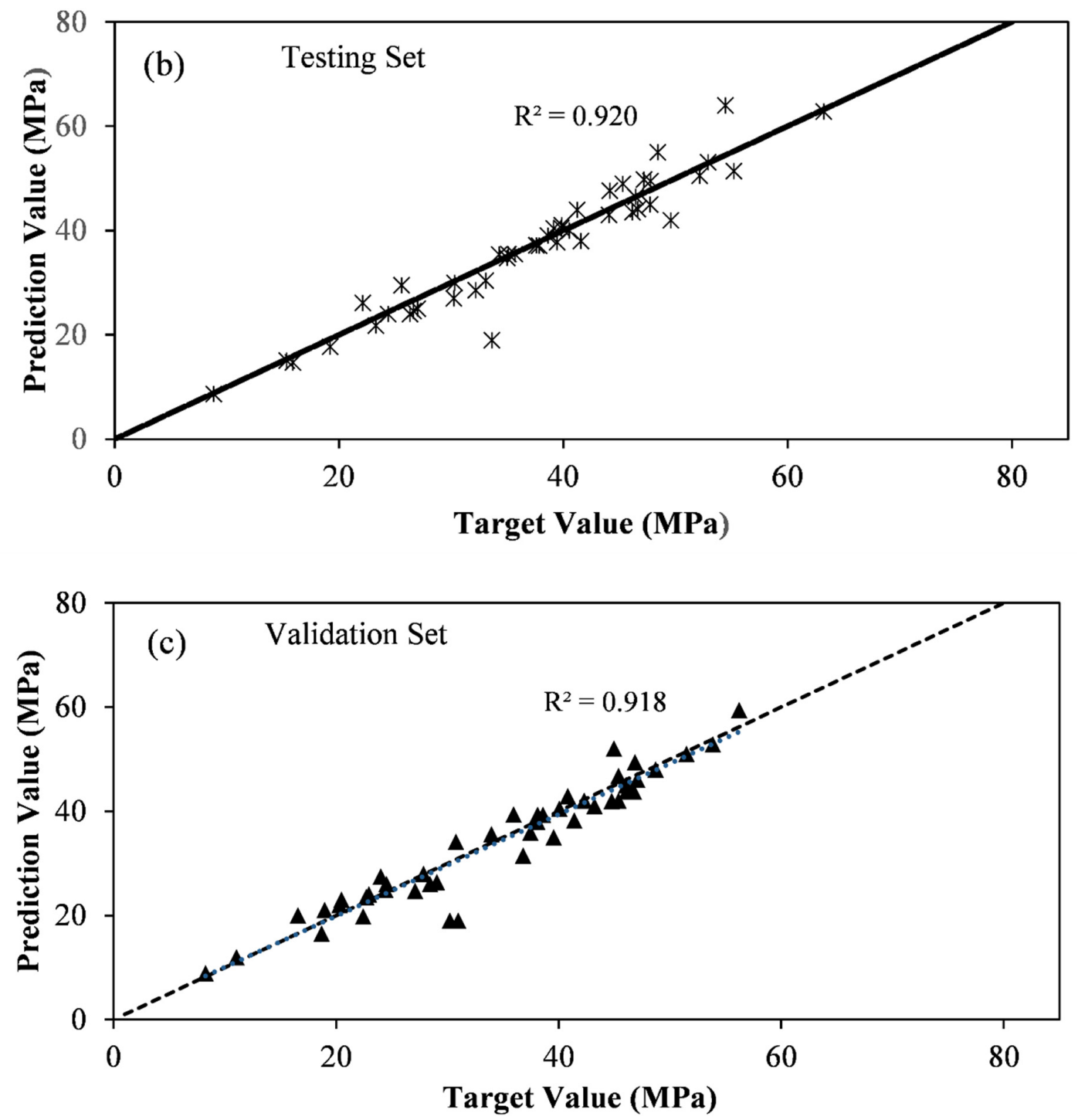

Figure 3. Experimental versus predicted compressive strength values for (a) the training set, (b) testing set, and (c) validation set.

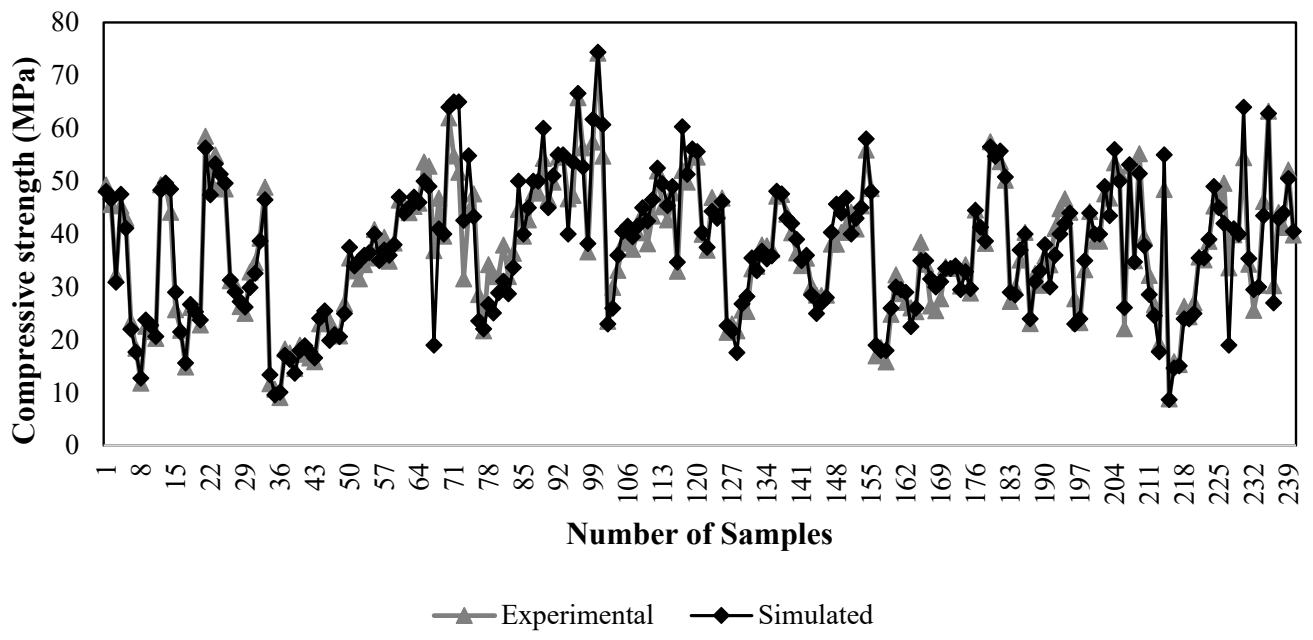

Figure 4. Comparison between the simulated and the experimental results in terms of compressive strength for all samples used in the ANN database. 


\subsection{Experimental Study for Validation of the Model}

To fully validate the developed ANN model, an experimental program was carried out. The completion of this program involved the collection of experimental results on the compressive strength at 7,28,60,90, and 180 days from different mixtures made of recycled concrete at a water-binder ratio of 0.36 . Four types of self-compacting sand concrete (SCSC), which is considered as a kind of SCC that contains aggregates with size of less than $5 \mathrm{~mm}$, were prepared by replacing $100 \%$ of natural aggregates (NA) and $40 \%$ of natural pozzolana (NP) by $100 \%$ of recycled aggregates (RA) and $40 \%$ fine recycled aggregates powder (FRCP), respectively. The constituent materials of concrete and their proportions were the same for different mixtures. The mixture compositions are given in Table 5.

Table 5. Mix proportions of concrete mixtures for $1 \mathrm{~m}^{3}$.

\begin{tabular}{ccccccccc}
\hline Sample & & & & $\begin{array}{c}\text { Fine Aggregates } \\
\mathbf{( k g / m ^ { 3 } )}\end{array}$ & Coarse Aggregates $\left(\mathbf{k g} / \mathbf{m}^{3}\right)$ & Additives \\
& $\begin{array}{c}\text { Binder } \\
\left(\mathrm{kg} / \mathrm{m}^{3}\right)\end{array}$ & $\mathrm{W}$ & $\mathrm{W} / \mathrm{B}$ & $\mathrm{S}\left(\mathrm{kg} / \mathrm{m}^{3}\right)$ & $\mathrm{NA}\left(\mathrm{kg} / \mathrm{m}^{3}\right)$ & $\mathrm{RCA}\left(\mathrm{kg} / \mathrm{m}^{3}\right)$ & $\mathrm{FRCP}\left(\mathrm{kg} / \mathrm{m}^{3}\right)$ & $\mathrm{NP}\left(\mathrm{kg} / \mathrm{m}^{3}\right)$ \\
\hline SCSC1 & 620 & 225 & 0.36 & 1213 & 303 & 0 & 0 & 170 \\
\hline RSCSC2 & 620 & 225 & 0.36 & 1213 & 0 & 303 & 0 & 170 \\
\hline RSCSC3 & 620 & 225 & 0.36 & 1213 & 303 & 0 & 0 \\
\hline RSCSC4 & 620 & 225 & 0.36 & 1213 & 0 & 303 & 170 \\
\hline
\end{tabular}

The used materials for the experimental part are described in Boudali et al. [38]. In all mixtures, Portland cement CEMII 42.5 B from local areas in Algeria was used to satisfy the requirements of EN 197 [39]. In terms of additives, natural pozzolana (NP) and fine recycled concrete powder (FRCP) were utilized. The NP was obtained from the deposit of Bouhamidi in the northwest of Algeria, in the Beni-Saf area, and FRCP was extracted by grinding the waste concrete. For superplasticizer, polycarboxylate-based, high-range, water-reducing admixture (HRWR) according to ASTM C494 [40] type F was used as an additive to the composite. The solids' content and specific gravity of the HRWR were $42 \%$ and 1.05 , respectively. Siliceous sand with a specific gravity of 2.56 and $0.4 \%$ of water absorption was considered as a fine aggregate.

Coarse aggregates, either natural or recycled, remained within the size range of 3 to $5 \mathrm{~mm}$. By crushing the construction waste, the used recycled aggregates were extracted in the West Algeria Public Works Laboratory. The compressive strength of recycled aggregates has an average of $40 \mathrm{MPa}$ and had specific gravity and water absorption of 2.54 and $2.5 \%$, respectively. Moreover, the average specific gravity and water absorption of natural aggregates were 2.58 and $1.3 \%$, respectively. Air entraining admixture (AEA) was considered in the order of 35-65 mL/100 kg binder aiming at a fresh air content of $5 \pm 1 \%$. Tap water was utilized throughout the experimental tests.

Mixtures' ingredients were mixed in a mechanical mixer in accordance with ASTM C 192 [41] (Standard Practice for Making and Curing Concrete Test Specimens in the Laboratory). The slump test, according to ASTM C 143, was conducted to evaluate the workability of the fresh concrete. Cube specimens $(7 \mathrm{~cm} \times 7 \mathrm{~cm} \times 7 \mathrm{~cm})$ were used for each specimen to conduct a compressive strength test. All compressive strength data were normalized based on the compressive strength results for control specimens made with natural aggregate at the same testing age. In addition, shape correction factors for the collected data were applied to eliminate specimen shape effects on the achieved strength following the Eurocode 2 [33] and recommendations from a previous study [34]. Specimens were produced according to NF P 18-400 [42]. The compressive strength of the samples was investigated after 7, 28, 60, 90, and 180 days of curing. Each reported compressive strength value represented the average of three identical samples.

The experimental results were used as unseen inputs to further validate the model (Table 6). The same 10 input parameters including binder content, water/binder 
ratio, natural aggregate, recycled concrete aggregate, natural pozzolana, fly ash, fine recycled aggregate powder, natural sand, recycled sand, and curing time were given to the developed ANN model and the compressive strength of RSCC as the target predicted by the model. For validating the model, the experimental compressive strengths of RSCC, i.e., the actual ones, were compared to the ones predicted by the model. It showed a good correlation, since the $\mathrm{R}^{2}$ value between the experimental and predicted compressive strength values was higher than 0.87 (Figure 5).

Table 6. Compressive strength values of mixtures were used as unseen inputs to further validate the model.

\begin{tabular}{ccccc}
\hline & \multicolumn{4}{c}{ CS (MPa) } \\
\hline Times (Days) & SCSC1 & RSCSC2 & RSCSC3 & RSCSC4 \\
\hline 7 & 24.25 & 25.22 & 26.19 & 27.16 \\
\hline 28 & 38.8 & 37.83 & 38.8 & 45.6 \\
\hline 60 & 43.65 & 43.65 & 47.53 & 53.35 \\
\hline 90 & 45.6 & 46.56 & 50.44 & 54.32 \\
\hline 180 & 47.53 & 49.5 & 53.35 & 55.94 \\
\hline
\end{tabular}

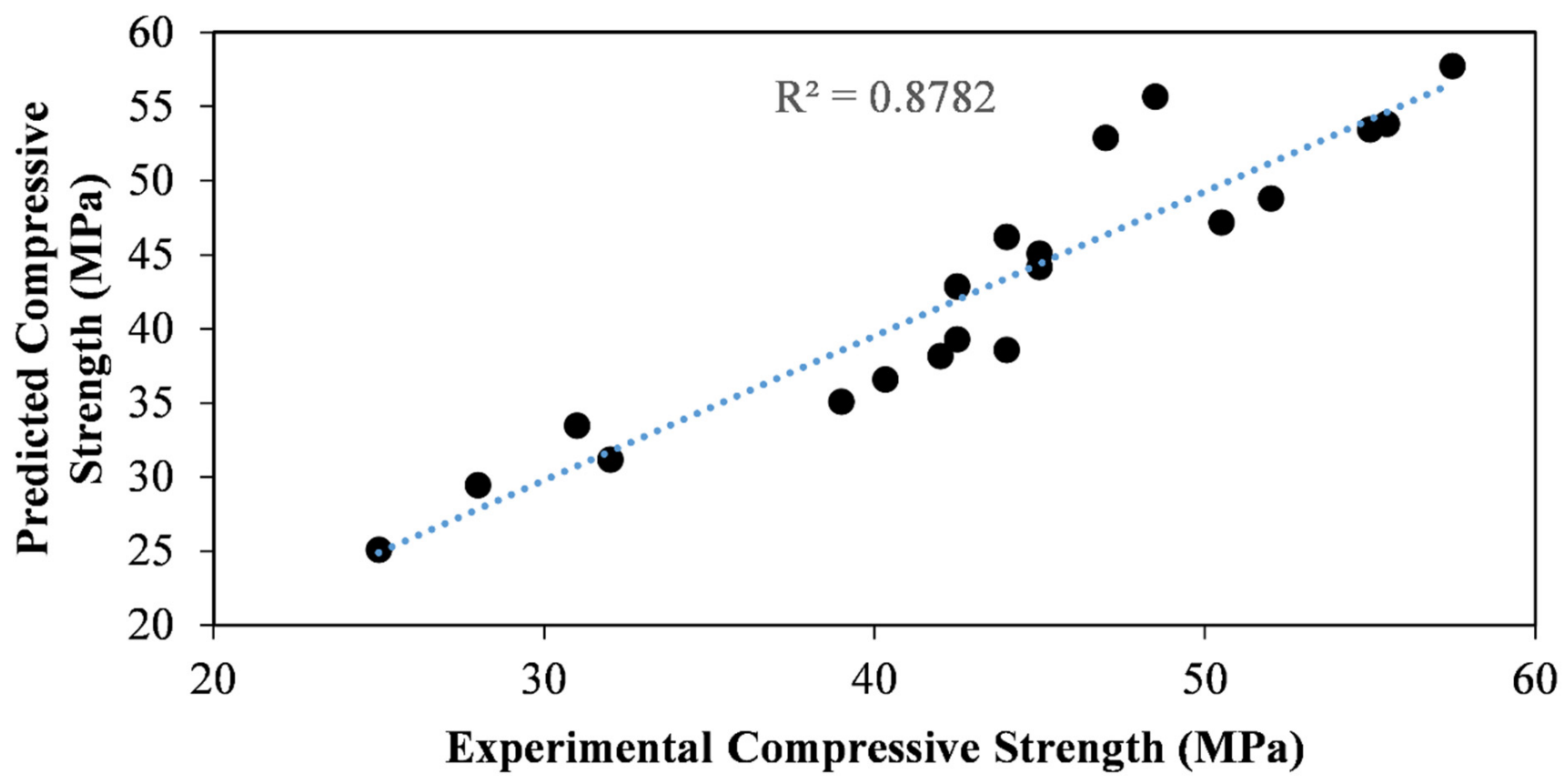

Figure 5. Predicted versus experimental compressive strength results.

\subsection{Parametric Analysis}

The developed model presented desirable performance and showed its capability for prediction of the compressive strength for different kinds of SCC mixture designs with various sizes of recycled aggregates. This section focuses on utilizing the capabilities of the model in capturing the effect of individual input variables on compressive strength progress. For the analysis, randomly selected concrete mixtures were introduced to the model as new mixtures with different levels within the range of training data of the parameter of interest. Out of the model inputs, the percentage of FRCP, RCA content, and FA were selected to highlight their effects on compressive strength development. Generally, obtained results were in agreement with previous findings by researchers [18], indicating the potential and high capability of the developed ANN model in predicting the performance. 


\subsubsection{Effect of Recycled Fine Aggregate Powder on Strength}

After validating the developed ANN model (i.e., $R^{2}$ and MAE values were $0.92 \%$ and $1.68 \%$, respectively), the model was used to evaluate the effect of incorporating different percentages of FRCP. Mixtures incorporating 20\%, 30\%, 35\%, and 40\% FRCP were introduced to the developed ANN model. The simulation results obtained for the recycled concrete compressive strength produced with different replacement levels of FRCP at curing days $(7,28,60,90$, and 180 days) are displayed in Figure 6 . In general, the compressive strength increased with time regardless of the amount of FRCP. Moreover, all tested mixtures exhibited compressive strengths above $32 \mathrm{MPa}$, which is the minimum decent concrete strength exposed to sulfate environment according to American Concrete Institute ACI Committee 318 [43]. One interesting point, the strength development rate differed as the FRCP amount exceeded $30 \%$. Hence, similar to conventional concrete behavior, mixtures incorporating more than $30 \%$ FRCP exhibited slightly low early strength at seven days, while exhibiting high strength later at 180 days. For mixtures incorporating $20 \%$ FRCP, the compressive strengths at ages 7 and 180 days were $38.43 \mathrm{MPa}$ and $46.31 \mathrm{MPa}$, respectively, indicating an increase of $28.3 \%$. For mixtures incorporating $40 \% \mathrm{FRCP}$, the compressive strengths at ages 7 and 180 days were $34.29 \mathrm{MPa}$ and $56.05 \mathrm{MPa}$, respectively, indicating an increase of $63.4 \%$. It should be noted that an increase in the FRCP content considerably increased the gain of compressive strength for concrete at ages 7 days to 180 days. In summary, a compressive strength increase of $28.3 \%$ (strengths at age 7 days vs. 180 days) was reported for concrete with $20 \% \mathrm{FRCP}$, while a more significant increase of $63.4 \%$ (strengths at age 7 days vs. 180 days) was reported for concrete with $40 \%$ FRCP. Adding such fine materials was expected to modify the particle size distribution and, consequently, the initial porosity of the mixture. It was noticed that the more added fine materials, the denser the microstructure. However, increasing the fine materials was going to increase the surface area and, consequently, the amount of absorbed water, leaving less free water for hydration during the early period. At later ages, mixtures with a higher amount of fine materials will possess a lower number of voids that need to be filled by hydration products. Hence, any slight continuation in hydration will have a higher impact on strengthening the microstructure. Moreover, FRCP has old, hydrated cement, i.e., calcium hydroxide (C.H.). This highlights the potential of having a pozzolanic reaction that directly contributes to strength development through enhancing interfacial transition zone (ITZ), which is responsible for the higher bond between aggregate/cement paste [44,45]. Therefore, the higher the added FRCP, the more the C.H. and pozzolanic reaction leading to higher later strength.

\subsubsection{Effect of Recycled Aggregate at Different FRAP Contents}

The influence of recycled aggregate content was quantified for a concrete mixture with $350 \mathrm{~kg}$ cement and a water cement ratio W/C of 0.5 . Three groups of mixtures were developed based on the FRCP content, which varied from $20 \%$ up to $35 \%$. In each group, RCA content was varied from $0 \%$ up to $100 \%$ of the total aggregate as a replacement for natural aggregates. Regardless of RCA content, the compressive strength of recycled concrete increased as curing time increased (Figure $7 \mathrm{a}-\mathrm{c}$ ). Also, increasing the percentage of RCA resulted in higher compressive strength. For instance, for the group of mixtures with $20 \%$ FRCP at 28 days, replacing NA with $50 \%$ and $100 \%$ RCA resulted in $14.7 \%$ and $38 \%$ increase in the achieved strength. This strength development was due to concrete hardening and probably the strong bond between the recycled coarse aggregates and the cement paste in addition to the good quality of recycled aggregates used. This behavior was following the results observed by previous works [44-48]. 


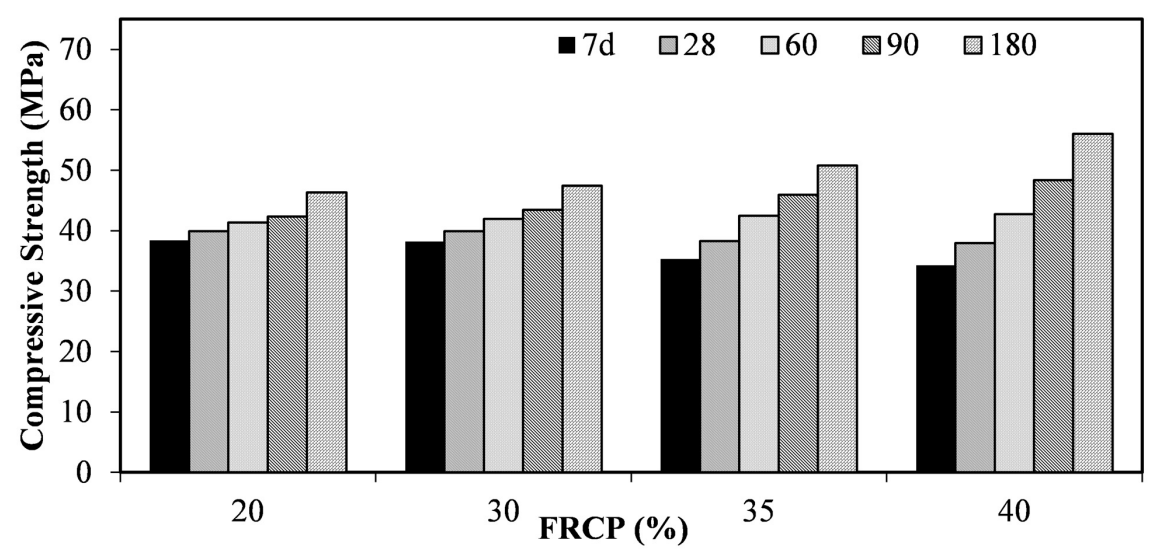

Figure 6. Simulation results of the RSCC compressive strength with 100\% NA and different FRCP contents.

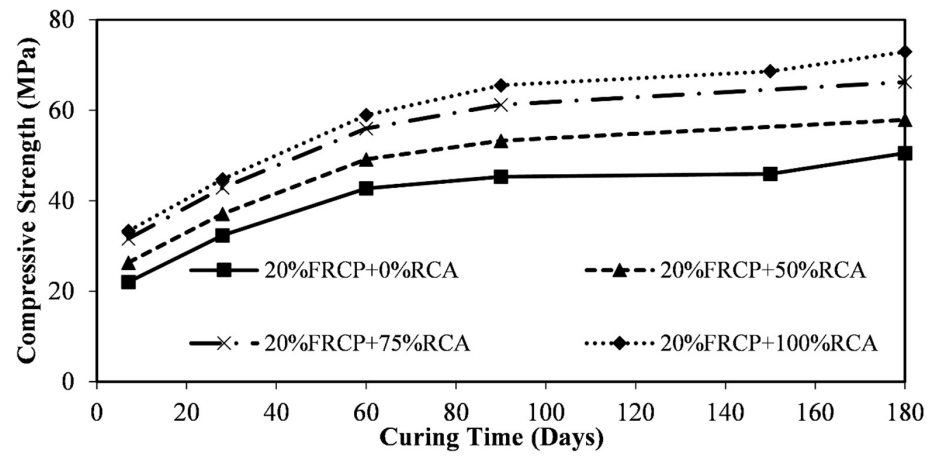

(a)

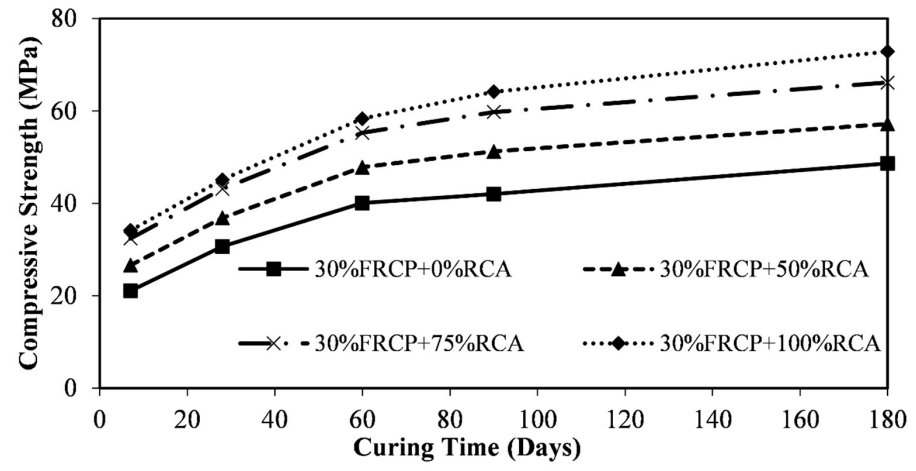

(b)

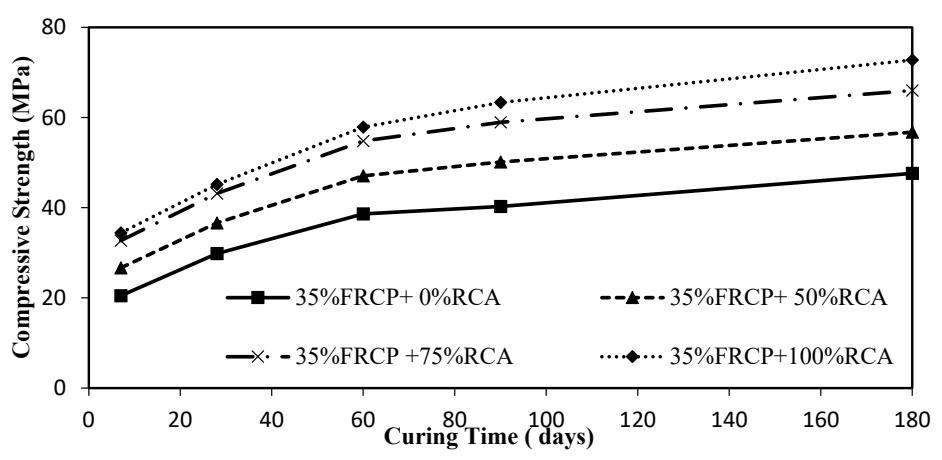

(c)

Figure 7. Simulation results of compressive strength of RSCC for different RCA contents (0-100\%) and three contents of FRCP: (a) $20 \%$, (b) $30 \%$, and (c) $35 \%$. 
The combination of RCA and FRCP significantly affected the compressive strength of the concrete mixture. There were small differences in the percentage of reduction of the compressive strength between the experimental results and the predicted ones provided by the ANN model. The difference in compressive strength values was about $0.95 \%$ (less than $1 \%$ ) for each age.

\subsubsection{Combined Effect between FRAP and Fly Ash}

Figure 8 shows the variations with the curing age of concrete compressive strengths for different contents of additives (fly ash contents and FRCP) at the same w/c ratio of 0.5 .

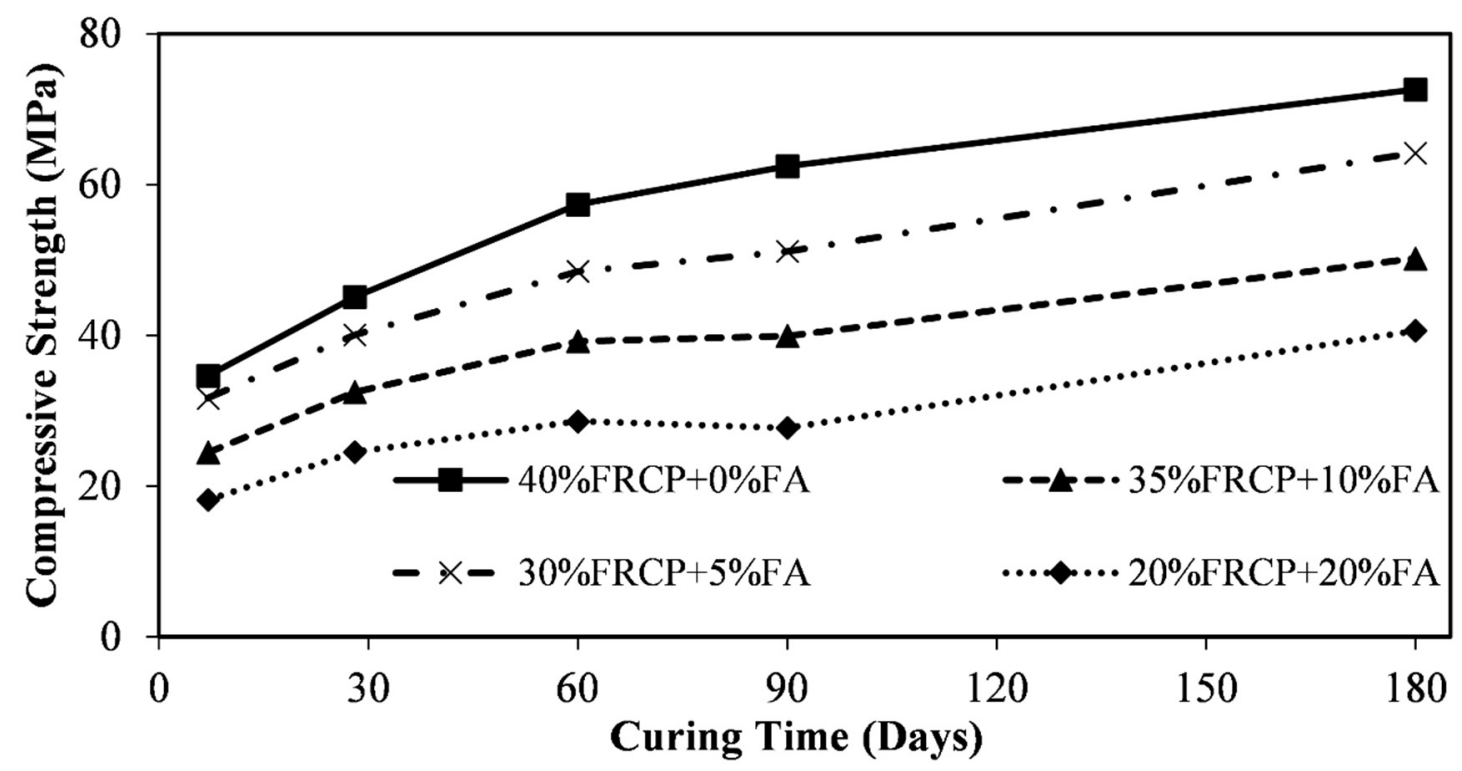

Figure 8. Simulation results of RSCC compressive strength produced from four combinations of FRCP and FA contents at different curing ages.

Generally, compressive strength increases with increasing curing age. For example, at 28 days, the compressive strength of concrete produced with 20 to $35 \%$ FRCP and 100\% RCA remained above $32 \mathrm{MPa}$. Further, using fly ash as a partial replacement of cement caused a decrease in the compressive strength. Looking more closely at the simulated results for the strength development between the 28- and 180-day results shows that the mixtures prepared with 5, 10, and $20 \%$ fly ash exhibited reductions in the compressive strength of $11 \%, 28 \%$, and $45.46 \%$ compared to the reference sample (i.e., $0 \%$ FA). On the other side, the combination of FRCP and fly ash significantly affected the compressive strength, as shown in Figure 8. In addition, the results from literature indicate that, with an increase in the FA content in recycled concrete produced with $100 \%$ RCA, the compressive strength decreases [26]. The existence of fly ash caused a decrease in the recycled concrete compressive strength, but the reductions were not critical in the long term (less than $11 \%$ at the curing age of 180 days) for the optimal mixture (100\% RCA, 35\% FRCP, and $10 \% \mathrm{FA})$. These results are consistent with previous findings showing that recycled aggregates (fine, powder) possess a particular self-cementing capacity [49].

Figure 9 depicts the influence of the fly ash percentage on the compressive strength of recycled concrete. As fly ash replacement level increased, the strength of concrete decreased. Using fly ash as a $5 \%$ substitution of ordinary cement and $40 \%$ FRCP substitution of natural pozzolanic influenced the strength. Its effect was marginal compared with 10, 15, and $20 \%$ FA. The presence of fly ash of less than $20 \%$ caused only a small decrease in the recycled concrete compressive strength compared to the conventional ones. A polynomial relationship between the additive contents (FRCP and/or FA) used and the compressive 
strength of RSCC was proposed to evaluate the properties over a wider set of curing days, more than 180 days (Figure 9).

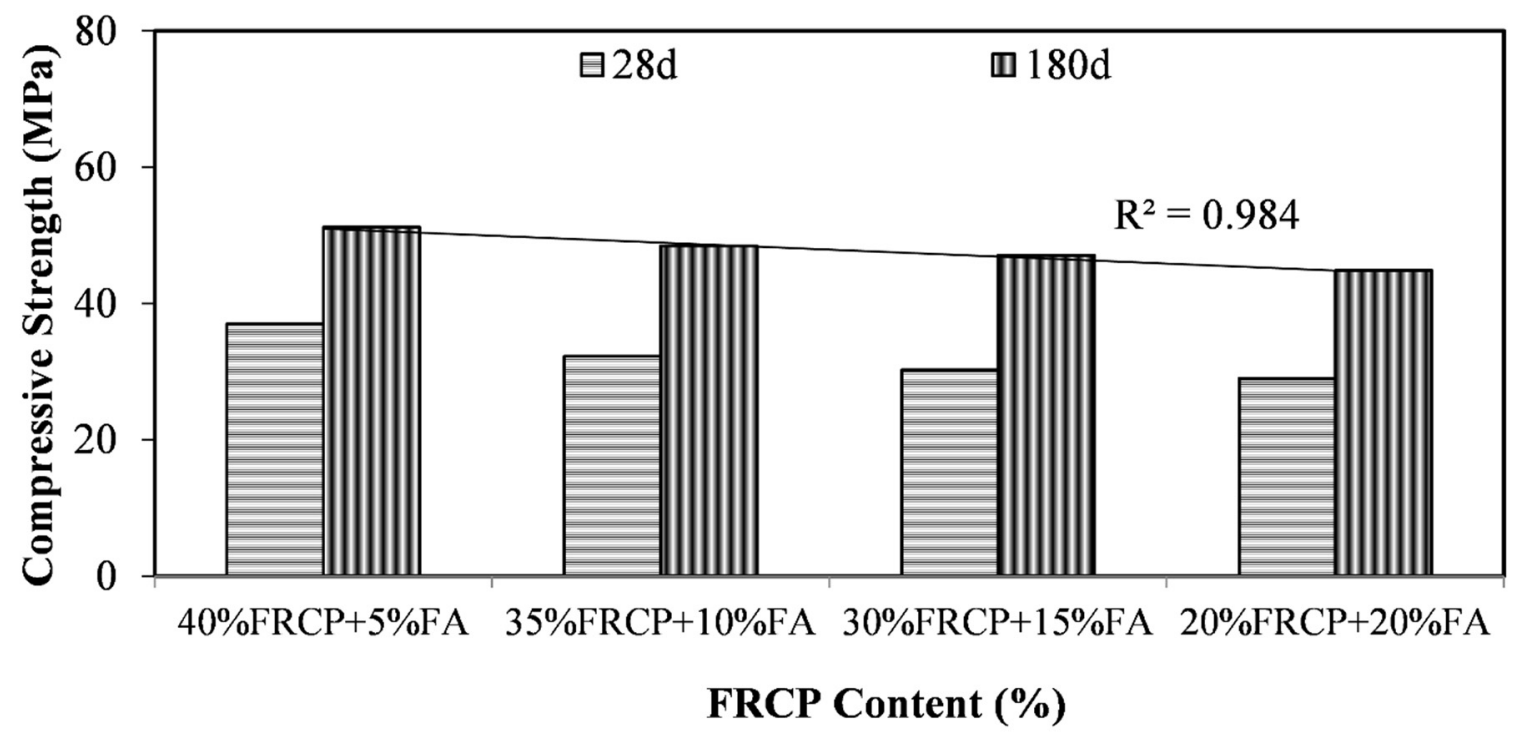

Figure 9. Simulation results of the effect of FRCP and FA contents on the strength of RSCC (100\% RCA) after 28 and 180 curing days.

\section{Conclusions}

In the current study, the influence of fine, recycled concrete powder on the compressive strength of recycled self-compacting concrete was investigated using an artificial neural network. The main results may be summarized as follows:

- The proposed ANN model provided good accuracy for the prediction of the compressive strength of RSCC in the data used for training. The regression values obtained for the training, testing, and validation steps were entirely satisfactory, namely, 0.97 , 0.96, and 0.96, respectively. The MSE of the model was 0.01. During the experimental validation, the regression value remained high (0.88). It can be expanded beyond the existing domain. Future experimental data are, however, required for such an extension.

- For validating the model, the actual experimental compressive strengths of RSCC were compared to the compressive strengths predicted by the model, showing a very good correlation $\left(\mathrm{R}^{2}\right.$ - value of 0.88$)$. Therefore, the results showed that the developed model can predict the compressive strength of RSCC with high accuracy.

- The type of aggregates, water absorption values, replacement level of RA and FRCP, and curing age can generally affect the properties of recycled concrete.

- The recycled self-compacting concrete compressive strength with any level of recycled aggregates can be significantly improved by using at least $40 \%$ of FRCP as cement replacement.

- The combination of fine, recycled concrete powder and recycled aggregates can have a positive effect on the mechanical properties of RSCC.

Incorporating fly ash ratio of less than $20 \%$ with recycled aggregates and fine, recycled aggregates did not show any significant effect on the compressive strength of RSCC.

Author Contributions: Conceptualization, S.B. and A.S.; methodology, S.B. and S.P., A.S.; software, S.B.; validation, S.B., and A.S.; formal analysis, S.B., B.A., A.H.R., S.P., and A.S.; investigation, S.B.; resources, S.P.; data curation, S.B.; writing—original draft preparation, S.B. and A.E.; writing—review and editing, S.P., and A.E.; visualization, S.B.; supervision, S.P., A.S.; project administration, S.B.; funding acquisition, S.B. All authors have read and agreed to the published version of the manuscript. 
Funding: This research received no external funding.

Institutional Review Board Statement: Not applicable.

Informed Consent Statement: Not applicable.

Data Availability Statement: The data presented in this study are available on request from the corresponding author.

Acknowledgments: S.B. and S.P. would like to acknowledge the support of the NSERC chair on industrial energy efficiency established at Universite de Sherbrooke in 2019 with the support of Hydro-Québec, Natural Resources Canada, and Emerson Canada.

Conflicts of Interest: The authors declare no conflict of interest. The funders had no role in the design of the study; in the collection, analyses, or interpretation of data; in the writing of the manuscript; or in the decision to publish the results. 


\section{Appendix A}

Table A1. Details of the experimental database [3,26,44,49-59].

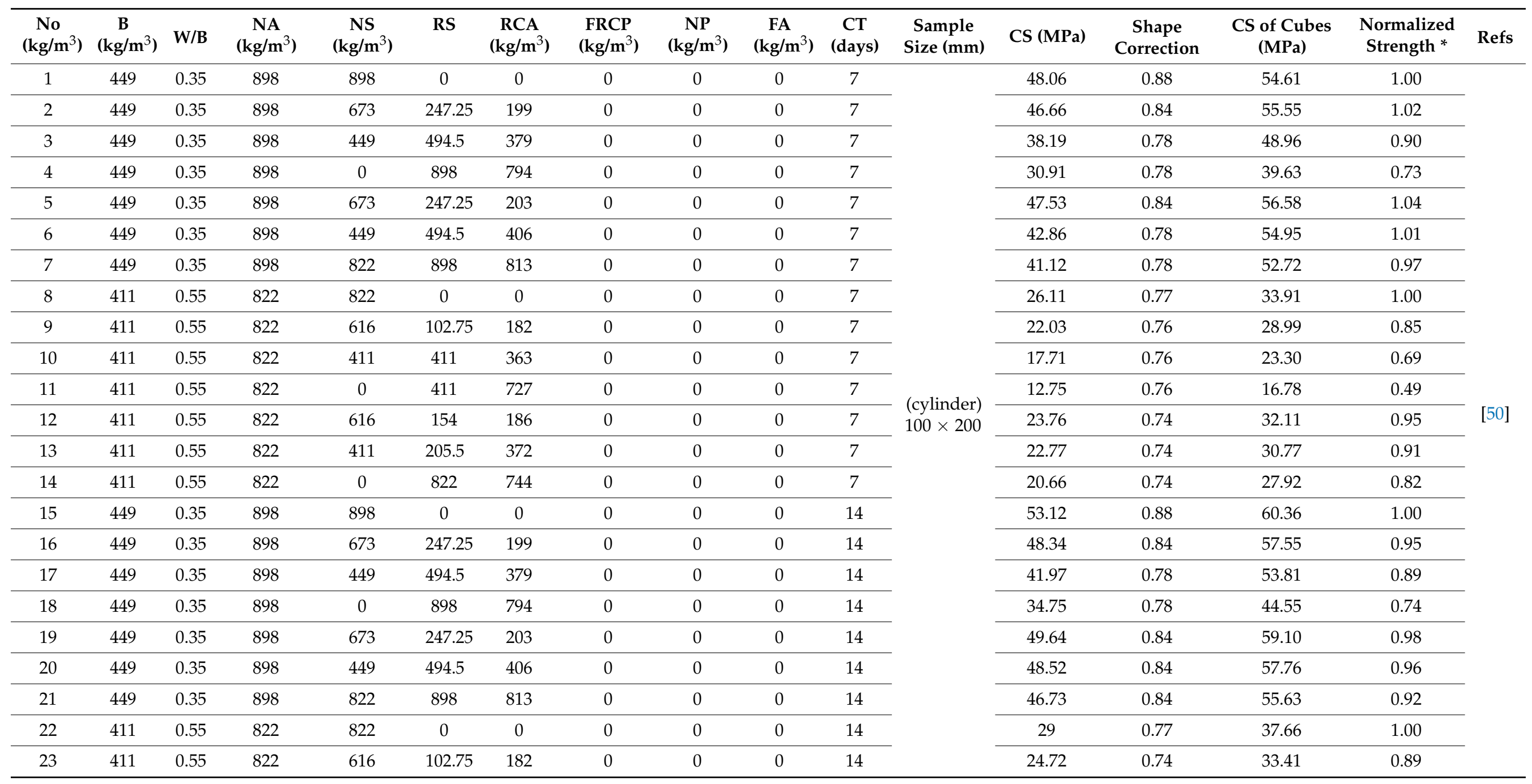


Table A1. Cont.

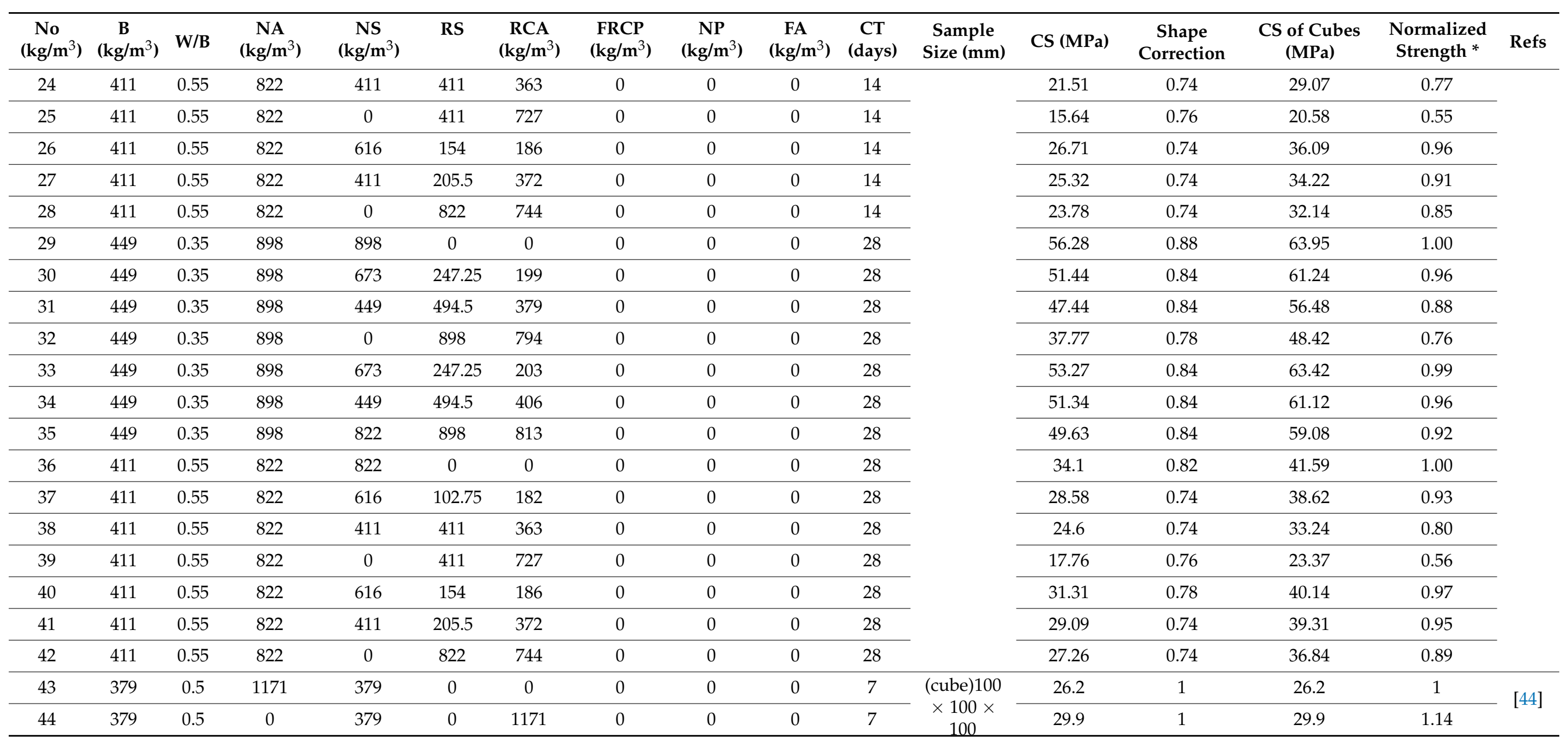


Table A1. Cont.

\begin{tabular}{|c|c|c|c|c|c|c|c|c|c|c|c|c|c|c|c|c|}
\hline $\begin{array}{l}\text { No } \\
\left(\mathrm{kg} / \mathrm{m}^{3}\right)\end{array}$ & $\begin{array}{c}B \\
\left(\mathrm{~kg} / \mathrm{m}^{3}\right)\end{array}$ & W/B & $\underset{\left(\mathrm{kg} / \mathrm{m}^{3}\right)}{\mathrm{NA}}$ & $\begin{array}{c}\mathrm{NS} \\
\left(\mathrm{kg} / \mathrm{m}^{3}\right)\end{array}$ & RS & $\begin{array}{c}\text { RCA } \\
\left(\mathrm{kg} / \mathrm{m}^{3}\right)\end{array}$ & $\begin{array}{l}\text { FRCP } \\
\left(\mathrm{kg} / \mathrm{m}^{3}\right)\end{array}$ & $\begin{array}{c}\mathrm{NP} \\
\left(\mathrm{kg} / \mathrm{m}^{3}\right)\end{array}$ & $\begin{array}{c}\text { FA } \\
\left(\mathrm{kg} / \mathrm{m}^{3}\right)\end{array}$ & $\begin{array}{c}\mathrm{CT} \\
\text { (days) }\end{array}$ & $\begin{array}{c}\text { Sample } \\
\text { Size }(\mathrm{mm})\end{array}$ & CS (MPa) & $\begin{array}{c}\text { Shape } \\
\text { Correction }\end{array}$ & $\begin{array}{c}\text { CS of Cubes } \\
\text { (MPa) }\end{array}$ & $\begin{array}{l}\text { Normalized } \\
\text { Strength * }\end{array}$ & Refs \\
\hline 45 & 379 & 0.5 & 1171 & 379 & 0 & 0 & 0 & 0 & 0 & 28 & \multirow{2}{*}{$\begin{array}{c}\text { (cube) } 100 \\
\times 100 \times \\
100\end{array}$} & 32.6 & 1 & 32.6 & 1 & \multirow{2}{*}{ [44] } \\
\hline 46 & 379 & 0.5 & 0 & 379 & 0 & 1171 & 0 & 0 & 0 & 28 & & 38.7 & 1 & 38.7 & 1.19 & \\
\hline 47 & 379 & 0.5 & 1171 & 379 & 0 & 0 & 0 & 0 & 0 & 90 & \multirow{3}{*}{$\begin{array}{c}\text { (cube) } 100 \\
\times 100 \times \\
100\end{array}$} & 46.5 & 1 & 46.5 & 1 & \multirow{3}{*}[44]{} \\
\hline 48 & 379 & 0.5 & 0 & 379 & 0 & 1171 & 0 & 0 & 0 & 90 & & 55 & 1 & 55 & 1.18 & \\
\hline 49 & 208 & 0.72 & 1040.7 & 807.6 & 0 & 0 & 0 & 0 & 52 & 7 & & 12 & 0.84 & 14.29 & 1.00 & \\
\hline 51 & 208 & 0.72 & 624.4 & 807.6 & 0 & 416.3 & 0 & 0 & 52 & 7 & \multirow{18}{*}{$\begin{array}{l}\text { (Cylinder) } \\
100 \times 200\end{array}$} & 9.6 & 0.76 & 12.63 & 0.88 & \multirow{18}{*}{ [51] } \\
\hline 52 & 208 & 0.72 & 520.4 & 807.6 & 0 & 520.4 & 0 & 0 & 52 & 7 & & 10.1 & 0.76 & 13.29 & 0.93 & \\
\hline 53 & 208 & 0.72 & 780.5 & 807.6 & 0 & 780.5 & 0 & 0 & 52 & 7 & & 8.7 & 0.76 & 11.45 & 0.80 & \\
\hline 54 & 208 & 0.72 & 1070.7 & 807.6 & 0 & 1040.7 & 0 & 0 & 52 & 7 & & 8.9 & 0.76 & 11.71 & 0.82 & \\
\hline 55 & 208 & 0.72 & 1040.7 & 807.6 & 0 & 0 & 0 & 0 & 52 & 28 & & 17.1 & 0.81 & 21.11 & 1.00 & \\
\hline 56 & 208 & 0.72 & 728.5 & 807.6 & 0 & 312.2 & 0 & 0 & 52 & 28 & & 16.5 & 0.76 & 21.71 & 1.03 & \\
\hline 58 & 208 & 0.72 & 520.4 & 807.6 & 0 & 520.4 & 0 & 0 & 52 & 28 & & 14.7 & 0.76 & 19.34 & 0.92 & \\
\hline 59 & 208 & 0.72 & 780.5 & 807.6 & 0 & 780.5 & 0 & 0 & 52 & 28 & & 15.1 & 0.76 & 19.87 & 0.94 & \\
\hline 60 & 208 & 0.72 & 1070.7 & 807.6 & 0 & 1040.7 & 0 & 0 & 52 & 28 & & 13.7 & 0.76 & 18.03 & 0.85 & \\
\hline 61 & 208 & 0.72 & 1040.7 & 807.6 & 0 & 0 & 0 & 0 & 52 & 56 & & 23 & 0.74 & 31.08 & 1.00 & \\
\hline 62 & 208 & 0.72 & 728.5 & 807.6 & 0 & 312.2 & 0 & 0 & 52 & 56 & & 22 & 0.76 & 28.95 & 0.93 & \\
\hline 63 & 208 & 0.72 & 624.4 & 807.6 & 0 & 416.3 & 0 & 0 & 52 & 56 & & 18 & 0.76 & 23.68 & 0.76 & \\
\hline 64 & 208 & 0.72 & 520.4 & 807.6 & 0 & 520.4 & 0 & 0 & 52 & 56 & & 18.9 & 0.76 & 24.87 & 0.80 & \\
\hline 65 & 208 & 0.72 & 780.5 & 807.6 & 0 & 780.5 & 0 & 0 & 52 & 56 & & 17.7 & 0.76 & 23.29 & 0.75 & \\
\hline 66 & 208 & 0.72 & 1070.7 & 807.6 & 0 & 1040.7 & 0 & 0 & 52 & 56 & & 16.6 & 0.76 & 21.84 & 0.70 & \\
\hline 67 & 208 & 0.72 & 1040.7 & 807.6 & 0 & 0 & 0 & 0 & 52 & 148 & & 24.1 & 0.77 & 31.30 & 1.00 & \\
\hline 68 & 208 & 0.72 & 728.5 & 807.6 & 0 & 312.2 & 0 & 0 & 52 & 148 & & 25.5 & 0.74 & 34.46 & 1.10 & \\
\hline 69 & 208 & 0.72 & 624.4 & 807.6 & 0 & 416.3 & 0 & 0 & 52 & 148 & & 19.9 & 0.76 & 26.18 & 0.84 & \\
\hline
\end{tabular}


Table A1. Cont.

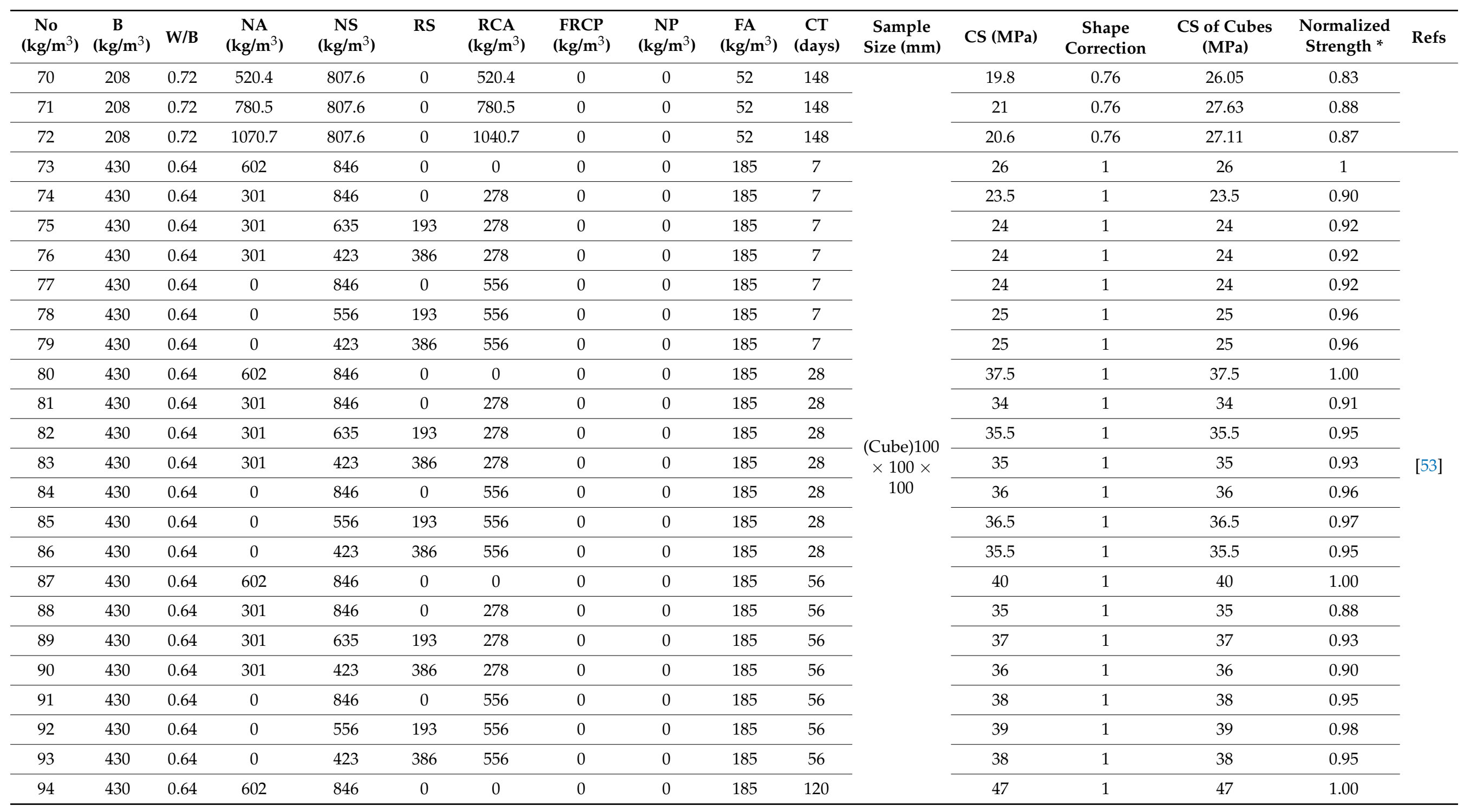


Table A1. Cont.

\begin{tabular}{|c|c|c|c|c|c|c|c|c|c|c|c|c|c|c|c|c|}
\hline $\begin{array}{c}\text { No } \\
\left(\mathrm{kg} / \mathrm{m}^{3}\right)\end{array}$ & $\begin{array}{c}\text { B } \\
\left(\mathrm{kg} / \mathrm{m}^{3}\right)\end{array}$ & W/B & $\underset{\left(\mathrm{kg} / \mathrm{m}^{3}\right)}{\mathrm{NA}}$ & $\begin{array}{c}\mathrm{NS} \\
\left(\mathrm{kg} / \mathrm{m}^{3}\right)\end{array}$ & RS & $\begin{array}{c}\text { RCA } \\
\left(\mathrm{kg} / \mathrm{m}^{3}\right)\end{array}$ & $\begin{array}{c}\text { FRCP } \\
\left(\mathrm{kg} / \mathrm{m}^{3}\right)\end{array}$ & $\begin{array}{c}\mathrm{NP} \\
\left(\mathrm{kg} / \mathrm{m}^{3}\right)\end{array}$ & $\underset{\left(\mathrm{kg} / \mathrm{m}^{3}\right)}{\text { FA }}$ & $\begin{array}{c}\mathrm{CT} \\
\text { (days) }\end{array}$ & $\begin{array}{c}\text { Sample } \\
\text { Size }(\mathrm{mm})\end{array}$ & CS (MPa) & $\begin{array}{c}\text { Shape } \\
\text { Correction }\end{array}$ & $\begin{array}{c}\text { CS of Cubes } \\
\text { (MPa) }\end{array}$ & $\begin{array}{l}\text { Normalized } \\
\text { Strength * }\end{array}$ & Refs \\
\hline 95 & 430 & 0.64 & 301 & 846 & 0 & 278 & 0 & 0 & 185 & 120 & & 41 & 1 & 41 & 0.87 & \\
\hline 96 & 430 & 0.64 & 301 & 635 & 193 & 278 & 0 & 0 & 185 & 120 & & 44 & 1 & 44 & 0.94 & \\
\hline 97 & 430 & 0.64 & 301 & 423 & 386 & 278 & 0 & 0 & 185 & 120 & & 42 & 1 & 42 & 0.89 & \\
\hline 98 & 430 & 0.64 & 0 & 846 & 0 & 556 & 0 & 0 & 185 & 120 & & 45 & 1 & 45 & 0.96 & \\
\hline 99 & 430 & 0.64 & 0 & 556 & 193 & 556 & 0 & 0 & 185 & 120 & & 47 & 1 & 47 & 1.00 & \\
\hline 101 & 310 & 0.4 & 1200 & 650 & 0 & 0 & 0 & 0 & 0 & 28 & \multirow{5}{*}{$\begin{array}{c}\text { (Cube) } 100 \\
\times 100 \times \\
100\end{array}$} & 50 & 1 & 50 & 1.00 & \multirow{5}{*}{ [54] } \\
\hline 102 & 310 & 0.4 & 920 & 650 & 0 & 140 & 0 & 0 & 0 & 28 & & 49 & 1 & 49 & 0.98 & \\
\hline 103 & 310 & 0.4 & 840 & 645 & 0 & 360 & 0 & 0 & 0 & 28 & & 49 & 1 & 49 & 0.98 & \\
\hline 104 & 310 & 0.4 & 590 & 640 & 0 & 590 & 0 & 0 & 0 & 28 & & 45 & 1 & 45 & 0.90 & \\
\hline 105 & 310 & 0.4 & 0 & 625 & 0 & 1170 & 0 & 0 & 0 & 28 & & 42 & 1 & 42 & 0.84 & \\
\hline 106 & 370 & 0.45 & 1215 & 650 & 0 & 0 & 0 & 0 & 0 & 7 & \multirow{11}{*}{$\begin{array}{c}\text { (Cube) } 100 \\
\times 100 \times \\
100\end{array}$} & 19 & 1 & 19 & 1 & \multirow{11}{*}{ [55] } \\
\hline 108 & 370 & 0.45 & 607.5 & 650 & 0 & 607.5 & 0 & 0 & 0 & 7 & & 19 & 1 & 19 & 1 & \\
\hline 109 & 370 & 0.45 & 0 & 650 & 0 & 1215 & 0 & 0 & 0 & 7 & & 19 & 1 & 19 & 1 & \\
\hline 110 & 370 & 0.45 & 1215 & 650 & 0 & 0 & 0 & 0 & 0 & 28 & & 41 & 1 & 41 & 1 & \\
\hline 111 & 370 & 0.45 & 850.5 & 650 & 0 & 364.5 & 0 & 0 & 0 & 28 & & 40 & 1 & 40 & 0.98 & \\
\hline 112 & 370 & 0.45 & 607.5 & 650 & 0 & 607.5 & 0 & 0 & 0 & 28 & & 41 & 1 & 41 & 1.00 & \\
\hline 113 & 370 & 0.45 & 0 & 650 & 0 & 1215 & 0 & 0 & 0 & 28 & & 40 & 1 & 40 & 0.98 & \\
\hline 114 & 370 & 0.45 & 1215 & 650 & 0 & 0 & 0 & 0 & 0 & 90 & & 64 & 1 & 64 & 1 & \\
\hline 115 & 370 & 0.45 & 850.5 & 650 & 0 & 364.5 & 0 & 0 & 0 & 90 & & 65 & 1 & 65 & 1.02 & \\
\hline 116 & 370 & 0.45 & 607.5 & 650 & 0 & 607.5 & 0 & 0 & 0 & 90 & & 64 & 1 & 64 & 1 & \\
\hline 117 & 370 & 0.45 & 0 & 650 & 0 & 1215 & 0 & 0 & 0 & 90 & & 65 & 1 & 65 & 1.02 & \\
\hline
\end{tabular}


Table A1. Cont.

\begin{tabular}{|c|c|c|c|c|c|c|c|c|c|c|c|c|c|c|c|c|}
\hline $\begin{array}{c}\text { No } \\
\left(\mathrm{kg} / \mathrm{m}^{3}\right)\end{array}$ & $\begin{array}{c}\text { B } \\
\left(\mathrm{kg} / \mathrm{m}^{3}\right)\end{array}$ & W/B & $\underset{\left(\mathrm{kg} / \mathrm{m}^{3}\right)}{\mathrm{NA}}$ & $\begin{array}{c}\mathrm{NS} \\
\left(\mathrm{kg} / \mathrm{m}^{3}\right)\end{array}$ & RS & $\begin{array}{c}\text { RCA } \\
\left(\mathrm{kg} / \mathrm{m}^{3}\right)\end{array}$ & $\begin{array}{c}\text { FRCP } \\
\left(\mathrm{kg} / \mathrm{m}^{3}\right)\end{array}$ & $\begin{array}{c}\mathrm{NP} \\
\left(\mathrm{kg} / \mathrm{m}^{3}\right)\end{array}$ & $\underset{\left(\mathrm{kg} / \mathrm{m}^{3}\right)}{\text { FA }}$ & $\begin{array}{c}\mathrm{CT} \\
\text { (days) }\end{array}$ & $\begin{array}{c}\text { Sample } \\
\text { Size }(\mathrm{mm})\end{array}$ & CS (MPa) & $\begin{array}{c}\text { Shape } \\
\text { Correction }\end{array}$ & $\begin{array}{c}\text { CS of Cubes } \\
\text { (MPa) }\end{array}$ & $\begin{array}{l}\text { Normalized } \\
\text { Strength * }\end{array}$ & Refs \\
\hline 118 & 400 & 0.48 & 1290 & 523 & 0 & 0 & 0 & 0 & 0 & 28 & \multirow{5}{*}{$\begin{array}{l}\text { (cylinder) } \\
160 \times 300\end{array}$} & 42.6 & 0.78 & 54.62 & 1 & \multirow{5}{*}{ [56] } \\
\hline 119 & 400 & 0.43 & 1140 & 685 & 0 & 0 & 0 & 0 & 0 & 28 & & 54.8 & 0.88 & 62.27 & 1 & \\
\hline 120 & 400 & 0.5 & 0 & 787 & 0 & 824 & 0 & 0 & 0 & 28 & & 43.3 & 0.82 & 52.80 & 1 & \\
\hline 121 & 400 & 0.65 & 0 & 0 & 629 & 878 & 0 & 0 & 0 & 28 & & 31.5 & 0.78 & 40.38 & 0.74 & \\
\hline 122 & 400 & 0.6 & 0 & 0 & 659 & 746 & 0 & 0 & 0 & 28 & & 35.4 & 0.78 & 45.38 & 0.83 & \\
\hline 124 & 360 & 0.65 & 1100 & 705 & 0 & 0 & 0 & 0 & 0 & 7 & \multirow{16}{*}{$\begin{array}{c}\text { (Cube) } 100 \\
\times 100 \times \\
100\end{array}$} & 17 & 1 & 17 & 1 & \multirow{16}{*}{ [3] } \\
\hline 125 & 360 & 0.65 & 0 & 705 & 0 & 1100 & 0 & 0 & 0 & 7 & & 15 & 1 & 15 & 0.89 & \\
\hline 126 & 380 & 0.5 & 1100 & 705 & 0 & 0 & 0 & 0 & 0 & 7 & & 21.2 & 1 & 21.2 & 1 & \\
\hline 127 & 380 & 0.5 & 0 & 705 & 0 & 1100 & 0 & 0 & 0 & 7 & & 18.9 & 1 & 18.9 & 1.10 & \\
\hline 128 & 400 & 0.48 & 1100 & 705 & 0 & 0 & 0 & 0 & 0 & 7 & & 24.7 & 1 & 24.7 & 1 & \\
\hline 129 & 400 & 0.48 & 0 & 705 & 0 & 1100 & 0 & 0 & 0 & 7 & & 22.7 & 1 & 22.7 & 0.92 & \\
\hline 131 & 420 & 0.43 & 0 & 705 & 0 & 1100 & 0 & 0 & 0 & 7 & & 26.5 & 1 & 26.5 & 0.82 & \\
\hline 132 & 460 & 0.4 & 1100 & 705 & 0 & 0 & 0 & 0 & 0 & 7 & & 37.3 & 1 & 37.3 & 1 & \\
\hline 133 & 460 & 0.4 & 0 & 705 & 0 & 1100 & 0 & 0 & 0 & 7 & & 27.8 & 1 & 27.8 & 0.76 & \\
\hline 134 & 360 & 0.65 & 1100 & 705 & 0 & 0 & 0 & 0 & 0 & 28 & & 22.7 & 1 & 22.7 & 1 & \\
\hline 135 & 360 & 0.65 & 0 & 705 & 0 & 1100 & 0 & 0 & 0 & 28 & & 20.3 & 1 & 20.3 & 0.90 & \\
\hline 136 & 380 & 0.5 & 1100 & 705 & 0 & 0 & 0 & 0 & 0 & 28 & & 32.3 & 1 & 32.3 & 1.00 & \\
\hline 137 & 380 & 0.5 & 0 & 705 & 0 & 1100 & 0 & 0 & 0 & 28 & & 29.2 & 1 & 29.2 & 0.91 & \\
\hline 138 & 400 & 0.48 & 1100 & 705 & 0 & 0 & 0 & 0 & 0 & 28 & & 36 & 1 & 36 & 1 & \\
\hline 139 & 400 & 0.48 & 0 & 705 & 0 & 1100 & 0 & 0 & 0 & 28 & & 32.2 & 1 & 32.3 & 0.90 & \\
\hline 140 & 420 & 0.43 & 1100 & 705 & 0 & 0 & 0 & 0 & 0 & 28 & & 46 & 1 & 46 & 1 & \\
\hline
\end{tabular}


Table A1. Cont.

\begin{tabular}{|c|c|c|c|c|c|c|c|c|c|c|c|c|c|c|c|c|}
\hline $\begin{array}{c}\text { No } \\
\left(\mathrm{kg} / \mathrm{m}^{3}\right)\end{array}$ & $\begin{array}{c}\text { B } \\
\left(\mathrm{kg} / \mathrm{m}^{3}\right)\end{array}$ & W/B & $\underset{\left(\mathrm{kg} / \mathrm{m}^{3}\right)}{\mathrm{NA}}$ & $\begin{array}{c}\mathrm{NS} \\
\left(\mathrm{kg} / \mathrm{m}^{3}\right)\end{array}$ & RS & $\begin{array}{c}\text { RCA } \\
\left(\mathrm{kg} / \mathrm{m}^{3}\right)\end{array}$ & $\begin{array}{l}\text { FRCP } \\
\left(\mathrm{kg} / \mathrm{m}^{3}\right)\end{array}$ & $\begin{array}{c}\mathrm{NP} \\
\left(\mathrm{kg} / \mathrm{m}^{3}\right)\end{array}$ & $\underset{\left(\mathrm{kg} / \mathrm{m}^{3}\right)}{\text { FA }}$ & $\begin{array}{c}\mathrm{CT} \\
\text { (days) }\end{array}$ & $\begin{array}{c}\text { Sample } \\
\text { Size }(\mathrm{mm})\end{array}$ & CS (MPa) & $\begin{array}{c}\text { Shape } \\
\text { Correction }\end{array}$ & $\begin{array}{c}\text { CS of Cubes } \\
\text { (MPa) }\end{array}$ & $\begin{array}{l}\text { Normalized } \\
\text { Strength * }\end{array}$ & Refs \\
\hline 141 & 420 & 0.43 & 0 & 705 & 0 & 1100 & 0 & 0 & 0 & 28 & \multirow{13}{*}{$\begin{array}{c}\text { (Cube) } 100 \\
\times 100 \times \\
100\end{array}$} & 39.4 & 1 & 39.4 & 0.86 & \\
\hline 142 & 460 & 0.4 & 1100 & 705 & 0 & 0 & 0 & 0 & 0 & 28 & & 53.5 & 1 & 53.5 & 1.34 & \\
\hline 143 & 460 & 0.4 & 0 & 705 & 0 & 1100 & 0 & 0 & 0 & 28 & & 46.5 & 1 & 46.5 & 0.87 & \\
\hline 144 & 325 & 0.5 & 1206.4 & 710.5 & 0 & 0 & 0 & 0 & 0 & 7 & & 50 & 1 & 50 & 1.00 & \multirow{10}{*}{ [57] } \\
\hline 145 & 325 & 0.5 & 0 & 660.7 & 0 & 1106.8 & 0 & 0 & 0 & 7 & & 40 & 1 & 40 & 0.81 & \\
\hline 147 & 365 & 0.4 & 0 & 586.8 & 0 & 1126.8 & 0 & 0 & 0 & 7 & & 50 & 1 & 50 & 1 & \\
\hline 148 & 365 & 0.4 & 0 & 586.5 & 0 & 1126.8 & 0 & 0 & 0 & 7 & & 50 & 1 & 50 & 1 & \\
\hline 149 & 325 & 0.5 & 0 & 660 & 0 & 1106.8 & 0 & 0 & 0 & 7 & & 35 & 1 & 35 & 0.71 & \\
\hline 150 & 325 & 0.5 & 1206.4 & 710.5 & 0 & 0 & 0 & 0 & 0 & 28 & & 60 & 1 & 60 & 1.00 & \\
\hline 151 & 325 & 0.5 & 0 & 660.7 & 0 & 1106.8 & 0 & 0 & 0 & 28 & & 45 & 1 & 45 & 0.76 & \\
\hline 152 & 345 & 0.43 & 0 & 613.9 & 0 & 1109.4 & 0 & 0 & 0 & 28 & & 51 & 1 & 51 & 0.85 & \\
\hline 154 & 365 & 0.4 & 0 & 586.5 & 0 & 1126.8 & 0 & 0 & 0 & 28 & & 55 & 1 & 55 & 0.92 & \\
\hline 155 & 325 & 0.5 & 0 & 660 & 0 & 1106.8 & 0 & 0 & 0 & 28 & & 40 & 1 & 40 & 0.68 & \\
\hline 156 & 250 & 0.6 & 1188 & 795 & 0 & 0 & 0 & 0 & 0 & 7 & \multirow{9}{*}{$\begin{array}{c}\text { (Cylinder) } \\
100 \times 200\end{array}$} & 35.9 & 0.82 & 43.78 & 1.00 & \multirow{9}{*}{ [58] } \\
\hline 157 & 250 & 0.6 & 0 & 795 & 0 & 1021 & 0 & 0 & 0 & 7 & & 30 & 0.74 & 40.54 & 0.93 & \\
\hline 158 & 350 & 0.45 & 1148 & 696 & 0 & 0 & 0 & 0 & 0 & 7 & & 53.6 & 0.88 & 60.91 & 1.00 & \\
\hline 159 & 350 & 0.45 & 0 & 696 & 0 & 1016 & 0 & 0 & 0 & 7 & & 43.8 & 0.82 & 53.41 & 0.88 & \\
\hline 160 & 450 & 0.35 & 1170 & 596 & 0 & 0 & 0 & 0 & 0 & 7 & & 66.6 & 0.88 & 75.68 & 1.00 & \\
\hline 161 & 450 & 0.35 & 0 & 596 & 0 & 1027 & 0 & 0 & 0 & 7 & & 52.7 & 0.84 & 62.74 & 0.83 & \\
\hline 162 & 350.25 & 0.45 & 861 & 696 & 0 & 254 & 0 & 0 & 0 & 7 & & 52 & 0.84 & 61.90 & 1.02 & \\
\hline 163 & 350.5 & 0.45 & 574 & 696 & 0 & 507 & 0 & 0 & 0 & 7 & & 49.4 & 0.84 & 58.81 & 0.97 & \\
\hline 164 & 250 & 0.6 & 1188 & 795 & 0 & 0 & 0 & 0 & 0 & 28 & & 43.5 & 0.82 & 53.05 & 1.00 & \\
\hline
\end{tabular}


Table A1. Cont.

\begin{tabular}{|c|c|c|c|c|c|c|c|c|c|c|c|c|c|c|c|c|}
\hline $\begin{array}{c}\text { No } \\
\left(\mathrm{kg} / \mathrm{m}^{3}\right)\end{array}$ & $\begin{array}{c}\text { B } \\
\left(\mathrm{kg} / \mathrm{m}^{3}\right)\end{array}$ & W/B & $\underset{\left(\mathrm{kg} / \mathrm{m}^{3}\right)}{\mathrm{NA}}$ & $\begin{array}{c}\mathrm{NS} \\
\left(\mathrm{kg} / \mathrm{m}^{3}\right)\end{array}$ & RS & $\begin{array}{c}\text { RCA } \\
\left(\mathrm{kg} / \mathrm{m}^{3}\right)\end{array}$ & $\begin{array}{c}\text { FRCP } \\
\left(\mathrm{kg} / \mathrm{m}^{3}\right)\end{array}$ & $\begin{array}{c}\mathrm{NP} \\
\left(\mathrm{kg} / \mathrm{m}^{3}\right)\end{array}$ & $\underset{\left(\mathrm{kg} / \mathrm{m}^{3}\right)}{\text { FA }}$ & $\begin{array}{c}\mathrm{CT} \\
\text { (days) }\end{array}$ & $\begin{array}{c}\text { Sample } \\
\text { Size }(\mathrm{mm})\end{array}$ & CS (MPa) & $\begin{array}{c}\text { Shape } \\
\text { Correction }\end{array}$ & $\begin{array}{c}\text { CS of Cubes } \\
\text { (MPa) }\end{array}$ & $\begin{array}{l}\text { Normalized } \\
\text { Strength * }\end{array}$ & Refs \\
\hline 165 & 250 & 0.6 & 0 & 795 & 0 & 1021 & 0 & 0 & 0 & 28 & & 38.2 & 0.82 & 46.59 & 0.88 & \\
\hline 166 & 350 & 0.45 & 1148 & 696 & 0 & 0 & 0 & 0 & 0 & 28 & & 61.7 & 0.88 & 70.11 & 1.00 & \\
\hline 167 & 350 & 0.45 & 0 & 696 & 0 & 1016 & 0 & 0 & 0 & 28 & & 52.8 & 0.84 & 62.86 & 0.90 & \\
\hline 168 & 450 & 0.35 & 1170 & 596 & 0 & 0 & 0 & 0 & 0 & 28 & & 74.4 & 0.88 & 84.55 & 1.00 & \\
\hline 169 & 450 & 0.35 & 0 & 596 & 0 & 1027 & 0 & 0 & 0 & 28 & & 62.8 & 0.84 & 74.76 & 0.88 & \\
\hline 171 & 350.5 & 0.45 & 574 & 696 & 0 & 507 & 0 & 0 & 0 & 28 & & 59.4 & 0.84 & 70.71 & 1.01 & \\
\hline 172 & 350 & 0.5 & 791 & 627.81 & 0 & 0 & 0 & 140 & 0 & 7 & \multirow{16}{*}{$\begin{array}{l}\text { (Cube) } 70 \\
\times 70 \times 70\end{array}$} & 25 & 0.97 & 24.25 & 1.00 & \multirow{16}{*}{ [26] } \\
\hline 173 & 350 & 0.5 & 0 & 627.81 & 0 & 791 & 0 & 140 & 0 & 7 & & 27 & 0.97 & 26.19 & 1.08 & \\
\hline 174 & 350 & 0.5 & 791 & 627.81 & 0 & 0 & 140 & 0 & 0 & 7 & & 28 & 0.97 & 27.16 & 1.12 & \\
\hline 175 & 350 & 0.5 & 0 & 627.81 & 0 & 791 & 140 & 0 & 0 & 7 & & 26 & 0.97 & 25.22 & 1.04 & \\
\hline 176 & 350 & 0.5 & 791 & 627.81 & 0 & 0 & 0 & 140 & 0 & 28 & & 40.33 & 0.97 & 39.12 & 1.00 & \\
\hline 178 & 350 & 0.5 & 791 & 627.81 & 0 & 0 & 140 & 0 & 0 & 28 & & 45.67 & 0.97 & 44.3 & 1.13 & \\
\hline 179 & 350 & 0.5 & 0 & 627.81 & 0 & 791 & 140 & 0 & 0 & 28 & & 44 & 0.97 & 42.68 & 1.09 & \\
\hline 180 & 350 & 0.5 & 791 & 627.81 & 0 & 0 & 0 & 140 & 0 & 90 & & 46.83 & 0.97 & 45.43 & 1.00 & \\
\hline 181 & 350 & 0.5 & 0 & 627.81 & 0 & 791 & 0 & 140 & 0 & 90 & & 47.67 & 0.97 & 46.24 & 1.02 & \\
\hline 182 & 350 & 0.5 & 791 & 627.81 & 0 & 0 & 0 & 140 & 0 & 28 & & 38 & 0.97 & 36.86 & 1.00 & \\
\hline 183 & 350 & 0.5 & 0 & 627.81 & 0 & 791 & 0 & 140 & 0 & 28 & & 40 & 0.97 & 38.8 & 1.05 & \\
\hline 184 & 350 & 0.5 & 791 & 627.81 & 0 & 0 & 140 & 0 & 0 & 28 & & 37 & 0.97 & 35.89 & 0.97 & \\
\hline 185 & 350 & 0.5 & 0 & 627.81 & 0 & 791 & 140 & 0 & 0 & 28 & & 42 & 0.97 & 40.74 & 1.11 & \\
\hline 186 & 350 & 0.5 & 791 & 627.81 & 0 & 0 & 0 & 140 & 0 & 90 & & 43 & 0.97 & 41.71 & 1.00 & \\
\hline 187 & 350 & 0.5 & 0 & 627.81 & 0 & 791 & 0 & 140 & 0 & 90 & & 45 & 0.97 & 43.65 & 1.05 & \\
\hline 188 & 350 & 0.5 & 791 & 627.81 & 0 & 0 & 140 & 0 & 0 & 90 & & 58 & 0.97 & 56.26 & 1.35 & \\
\hline
\end{tabular}


Table A1. Cont.

\begin{tabular}{|c|c|c|c|c|c|c|c|c|c|c|c|c|c|c|c|c|}
\hline $\begin{array}{c}\text { No } \\
\left(\mathrm{kg} / \mathrm{m}^{3}\right)\end{array}$ & $\begin{array}{c}\text { B } \\
\left(\mathrm{kg} / \mathrm{m}^{3}\right)\end{array}$ & W/B & $\underset{\left(\mathrm{kg} / \mathrm{m}^{3}\right)}{\mathrm{NA}}$ & $\begin{array}{c}\mathrm{NS} \\
\left(\mathrm{kg} / \mathrm{m}^{3}\right)\end{array}$ & RS & $\begin{array}{c}\text { RCA } \\
\left(\mathrm{kg} / \mathrm{m}^{3}\right)\end{array}$ & $\begin{array}{l}\text { FRCP } \\
\left(\mathrm{kg} / \mathrm{m}^{3}\right)\end{array}$ & $\begin{array}{c}\mathrm{NP} \\
\left(\mathrm{kg} / \mathrm{m}^{3}\right)\end{array}$ & $\underset{\left(\mathrm{kg} / \mathrm{m}^{3}\right)}{\text { FA }}$ & $\begin{array}{c}\mathrm{CT} \\
\text { (days) }\end{array}$ & $\begin{array}{c}\text { Sample } \\
\text { Size }(\mathrm{mm})\end{array}$ & CS (MPa) & $\begin{array}{c}\text { Shape } \\
\text { Correction }\end{array}$ & $\begin{array}{l}\text { CS of Cubes } \\
\text { (MPa) }\end{array}$ & $\begin{array}{l}\text { Normalized } \\
\text { Strength * }\end{array}$ & Refs \\
\hline 189 & 350 & 0.5 & 0 & 627.81 & 0 & 791 & 140 & 0 & 0 & 90 & & 48 & 0.97 & 46.56 & 1.12 & \\
\hline 190 & 350 & 0.5 & 791 & 627.81 & 0 & 0 & 0 & 140 & 0 & 180 & & 48 & 0.97 & 46.56 & 1.00 & \\
\hline 191 & 350 & 0.5 & 0 & 627.81 & 0 & 791 & 0 & 140 & 0 & 180 & & 50.5 & 0.97 & 48.99 & 1.05 & \\
\hline 192 & 350 & 0.5 & 791 & 627.81 & 0 & 0 & 140 & 0 & 0 & 180 & & 60.17 & 0.97 & 58.36 & 1.25 & \\
\hline 193 & 350 & 0.5 & 0 & 627.81 & 0 & 791 & 140 & 0 & 0 & 180 & & 52 & 0.97 & 50.44 & 1.08 & \\
\hline 195 & 325 & 0.2 & 0 & 660.7 & 0 & 1106.8 & 0 & 0 & 0 & 7 & \multirow{17}{*}{$\begin{array}{l}\text { (cylinder) } \\
100 \times 200\end{array}$} & 40.5 & 0.78 & 51.92 & 0.88 & \multirow{17}{*}{ [49] } \\
\hline 196 & 345 & 0.43 & 0 & 613.9 & 0 & 1109.4 & 0 & 0 & 0 & 7 & & 45.4 & 0.84 & 54.05 & 0.92 & \\
\hline 197 & 365 & 0.4 & 0 & 586.8 & 0 & 1126.8 & 0 & 0 & 0 & 7 & & 49 & 0.84 & 58.33 & 0.99 & \\
\hline 198 & 365 & 0.4 & 0 & 586.8 & 0 & 1126.8 & 0 & 0 & 0 & 7 & & 49.5 & 0.84 & 58.93 & 1.00 & \\
\hline 199 & 325 & 0.52 & 0 & 660.7 & 0 & 1106.8 & 0 & 0 & 0 & 7 & & 34.7 & 0.78 & 44.49 & 0.75 & \\
\hline 200 & 325 & 0.5 & 0 & 710.5 & 0 & 1206.5 & 0 & 0 & 0 & 28 & & 60.3 & 0.88 & 68.52 & 1.16 & \\
\hline 202 & 345 & 0.43 & 0 & 613.9 & 0 & 1109.4 & 0 & 0 & 0 & 28 & & 51.3 & 0.84 & 61.07 & 1.04 & \\
\hline 203 & 365 & 0.4 & 0 & 586.8 & 0 & 1126.8 & 0 & 0 & 0 & 28 & & 56.1 & 0.84 & 66.79 & 1.13 & \\
\hline 204 & 365 & 0.4 & 0 & 586.8 & 0 & 1126.8 & 0 & 0 & 0 & 28 & & 55.6 & 0.84 & 66.19 & 1.12 & \\
\hline 205 & 325 & 0.52 & 0 & 660.7 & 0 & 1106.8 & 0 & 0 & 0 & 28 & & 40.3 & 0.78 & 51.67 & 0.88 & \\
\hline 206 & 300 & 0.55 & 1206.97 & 765.13 & 0 & 0 & 0 & 0 & 0 & 7 & & 37.13 & 0.82 & 45.28 & 1.00 & \\
\hline 207 & 300 & 0.55 & 787.4 & 765.1 & 0 & 1042.6 & 0 & 0 & 0 & 7 & & 40.5 & 0.78 & 51.92 & 1.1 & \\
\hline 208 & 318 & 0.52 & 1145.3 & 739 & 0 & 888.7 & 0 & 0 & 0 & 7 & & 37.5 & 0.78 & 48.08 & 1.1 & \\
\hline 209 & 325 & 0.5 & 1806.6 & 683.2 & 0 & 1123.4 & 0 & 0 & 0 & 7 & & 40.4 & 0.78 & 51.79 & 1.1 & \\
\hline 210 & 300 & 0.55 & 1206.97 & 765.13 & 0 & 0 & 0 & 0 & 0 & 28 & & 44.3 & 0.82 & 54.02 & 1 & \\
\hline 211 & 300 & 0.55 & 787.4 & 765.1 & 0 & 1042.6 & 0 & 0 & 0 & 28 & & 46 & 0.84 & 54.76 & 1.01 & \\
\hline 212 & 318 & 0.52 & 1145.3 & 739 & 0 & 888.7 & 0 & 0 & 0 & 28 & & 43 & 0.78 & 55.13 & 1.01 & \\
\hline
\end{tabular}


Table A1. Cont.

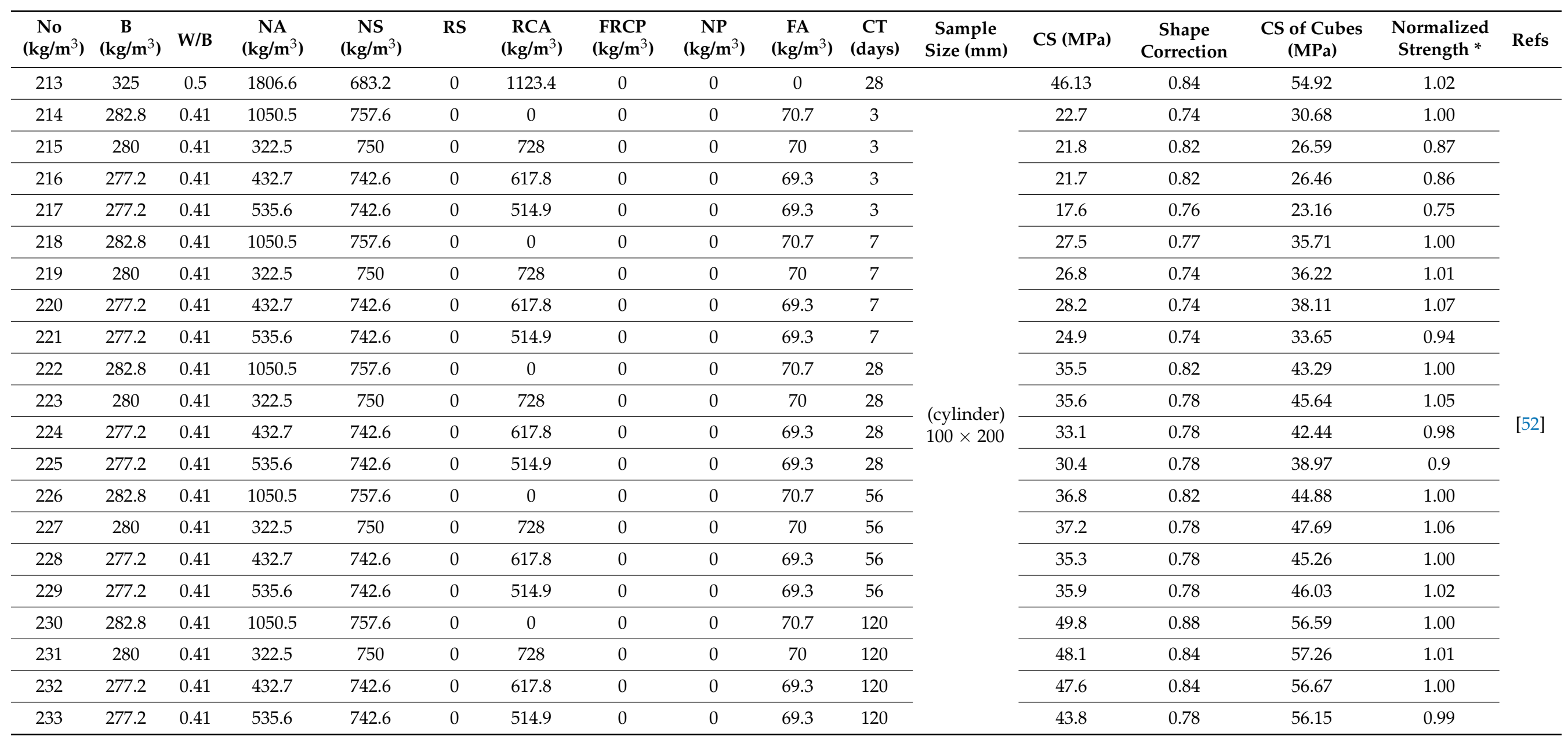


Table A1. Cont.

\begin{tabular}{|c|c|c|c|c|c|c|c|c|c|c|c|c|c|c|c|c|}
\hline $\begin{array}{c}\text { No } \\
\left(\mathrm{kg} / \mathrm{m}^{3}\right)\end{array}$ & $\begin{array}{c}\text { B } \\
\left(\mathrm{kg} / \mathrm{m}^{3}\right)\end{array}$ & W/B & $\underset{\left(\mathrm{kg} / \mathrm{m}^{3}\right)}{\mathrm{NA}}$ & $\begin{array}{c}\mathrm{NS} \\
\left(\mathrm{kg} / \mathrm{m}^{3}\right)\end{array}$ & RS & $\begin{array}{c}\text { RCA } \\
\left(\mathrm{kg} / \mathrm{m}^{3}\right)\end{array}$ & $\begin{array}{l}\text { FRCP } \\
\left(\mathrm{kg} / \mathrm{m}^{3}\right)\end{array}$ & $\begin{array}{c}\mathrm{NP} \\
\left(\mathrm{kg} / \mathrm{m}^{3}\right)\end{array}$ & $\begin{array}{c}\text { FA } \\
\left(\mathrm{kg} / \mathrm{m}^{3}\right)\end{array}$ & $\begin{array}{c}\mathrm{CT} \\
\text { (days) }\end{array}$ & $\begin{array}{c}\text { Sample } \\
\text { Size }(\mathrm{mm})\end{array}$ & CS (MPa) & $\begin{array}{c}\text { Shape } \\
\text { Correction }\end{array}$ & $\begin{array}{l}\text { CS of Cubes } \\
(\mathrm{MPa})\end{array}$ & $\begin{array}{l}\text { Normalized } \\
\text { Strength * }\end{array}$ & Refs \\
\hline 234 & 350 & 0.53 & 860 & 1050 & 0 & 0 & 0 & 0 & 0 & 28 & \multirow{6}{*}{$\begin{array}{c}\text { (Cube) } 100 \\
\times 100 \times \\
100\end{array}$} & 44.1 & 1 & 44.1 & 1.00 & \multirow{6}{*}{ [59] } \\
\hline 235 & 350 & 0.53 & 860 & 946 & 105 & 0 & 0 & 0 & 0 & 28 & & 43 & 1 & 43 & 0.98 & \\
\hline 236 & 350 & 0.53 & 860 & 840 & 210 & 0 & 0 & 0 & 0 & 28 & & 42 & 1 & 42 & 0.95 & \\
\hline 237 & 350 & 0.53 & 860 & 735 & 315 & 0 & 0 & 0 & 0 & 28 & & 39 & 1 & 39 & 0.88 & \\
\hline 238 & 350 & 0.53 & 860 & 630 & 420 & 0 & 0 & 0 & 0 & 28 & & 35 & 1 & 35 & 0.79 & \\
\hline 240 & 350 & 0.53 & 860 & 0 & 1050 & 0 & 0 & 0 & 0 & 28 & & 28.5 & 1 & 28.5 & 0.65 & \\
\hline
\end{tabular}

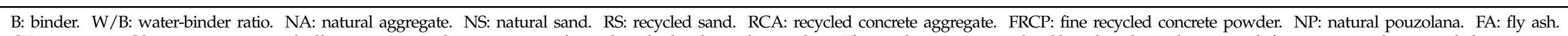

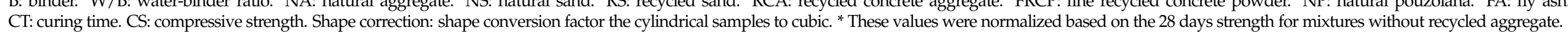




\section{References}

1. Kou, S.C.; Poon, C.S.; Chan, D. Influence of fly ash as a cement addition on the hardened properties of recycled aggregate concrete. Mater. Struct. 2007, 41, 1191-1201. [CrossRef]

2. Huseien, G.F.; Shah, K.W. Durability and life cycle evaluation of self-compacting concrete containing fly ash as GBFS replacement with alkali activation. Constr. Build. Mater. 2020, 235, 117458. [CrossRef]

3. Rahal, K. Mechanical properties of concrete with recycled coarse aggregate. Build. Environ. 2007, 42, 407-415. [CrossRef]

4. Chakkamalayath, J.; Joseph, A.; Al-Baghli, H.; Hamadah, O.; Dashti, D.; Abdulmalek, N. Performance evaluation of selfcompacting concrete containing volcanic ash and recycled coarse aggregates. Asian J. Civ. Eng. 2020, 21, 815-827. [CrossRef]

5. Sonebi, M. Medium strength self-compacting concrete containing fly ash: Modelling using factorial experimental plans. Cem. Concr. Res. 2004, 34, 1199-1208. [CrossRef]

6. Panda, K.; Bal, P. Properties of Self Compacting Concrete Using Recycled Coarse Aggregate. Procedia Eng. 2013, 51, 159-164. [CrossRef]

7. Wang, Y.L.; Wang, W.D.; Guan, X.M. Physical Filling Effects of Limestone Powders with Different Particle Size. Adv. Mater. Res. 2010, 163-167, 1419-1424. [CrossRef]

8. Safiuddin, M.D.; Salam, M.A.; Jumaat, M.Z. Effects of recycled concrete aggregate on the fresh properties of self-consolidating concrete. Arch. Civ. Mech. Eng. 2011, 11, 1023-1041. [CrossRef]

9. Kou, S.; Poon, C. Properties of self-compacting concrete prepared with coarse and fine recycled concrete aggregates. Cem. Concr. Compos. 2009, 31, 622-627. [CrossRef]

10. Sasanipour, H.; Aslani, F. Durability properties evaluation of self-compacting concrete prepared with waste fine and coarse recycled concrete aggregates. Constr. Build. Mater. 2020, 236, 117540. [CrossRef]

11. González-Taboada, I.; González-Fonteboa, B.; Martínez-Abella, F.; Pérez-Ordóñez, J.L. Prediction of the mechanical properties of structural recycled concrete using multivariable regression and genetic programming. Constr. Build. Mater. 2016, 106, 480-499. [CrossRef]

12. Younis, K.H.; Pilakoutas, K. Strength prediction model and methods for improving recycled aggregate concrete. Constr. Build. Mater. 2013, 49, 688-701. [CrossRef]

13. Féret, R. Sur la compacité des matériaux hydrauliques. Ann. Ponts Chaussées. 1982, 4, 5-164.

14. Yang, J.; Du, Q.; Bao, Y. Concrete with recycled concrete aggregate and crushed clay bricks. Constr. Build. Mater. 2011, 25, 1935-1945. [CrossRef]

15. Rebouh, R.; Boukhatem, B.; Ghrici, M.; Tagnit-Hamou, A. A practical hybrid NNGA system for predicting the compressive strength of concrete containing natural pozzolan using an evolutionary structure. Constr. Build. Mater. 2017, 149, 778-789. [CrossRef]

16. Ni, H.-G.; Wang, J.-Z. Prediction of compressive strength of concrete by neural networks. Cem. Concr. Res. 2000, 30, 1245-1250. [CrossRef]

17. Duan, Z.; Kou, S.; Poon, C. Prediction of compressive strength of recycled aggregate concrete using artificial neural networks. Constr. Build. Mater. 2013, 40, 1200-1206. [CrossRef]

18. Topçu, İ.B.; Sarıdemir, M. Prediction of properties of waste AAC aggregate concrete using artificial neural network. Comput. Mater. Sci. 2007, 41, 117-125. [CrossRef]

19. Kasperkiewicz, J.; Racz, J.; Dubrawski, A. HPC Strength Prediction Using Artificial Neural Network. J. Comput. Civ. Eng. 1995, 9, 279-284. [CrossRef]

20. Yeh, I.-C. Design of High-Performance Concrete Mixture Using Neural Networks and Nonlinear Programming. J. Comput. Civ. Eng. 1999, 13, 36-42. [CrossRef]

21. Uysal, M.; Tanyildizi, H. Predicting the core compressive strength of self-compacting concrete (SCC) mixtures with mineral additives using artificial neural network. Constr. Build. Mater. 2011, 25, 4105-4111. [CrossRef]

22. Fan, C.-C.; Huang, R.; Hwang, H.; Chao, S.-J. The Effects of Different Fine Recycled Concrete Aggregates on the Properties of Mortar. Materials 2015, 8, 2658-2672. [CrossRef]

23. Zhou, C.; Chen, Z. Mechanical properties of recycled concrete made with different types of coarse aggregate. Constr. Build. Mater. 2017, 134, 497-506. [CrossRef]

24. Lee, B.Y.; Kim, J.H.; Kim, J.-K. Optimum concrete mixture proportion based on a database considering regional characteristics. J. Comput. Civ. Eng. 2009, 23, 258-265. [CrossRef]

25. Transportation Research Circulars. Use of Artificial Neural Networks in Geomechanical and Pavement Systems; Number E-C012; Transportation Research Board, National Research Council: Washington, DC, USA, 1999.

26. Boudali, S.; Kerdal, D.; Ayed, K.; Abdulsalam, B.; Soliman, A. Performance of self-compacting concrete incorporating recycled concrete fines and aggregate exposed to sulphate attack. Constr. Build. Mater. 2016, 124, 705-713. [CrossRef]

27. Haykin, S. Neural Networks: A Comprehensive Foundation; Prentice Hall: Upper Saddle River, NJ, USA, 1999.

28. Trabelsi, S.; Hafid, M.; Poncet, S.; Poirier, M.; Lacroix, M. Rheology of ethylene- and propylene-glycol ice slurries: Experiments and ANN model. Int. J. Refrig. 2017, 82, 447-460. [CrossRef]

29. Samui, P.; Das, S.D.; Sitharam, T.G. Intelligent and Soft Computing in Infrastructure Systems Engineering; Intel. \& Soft Comp. in Infra. Sys. Eng., SCI 259; Gopalakrishnan, K., Ceylan, H., Attoh-Okine, N.O., Eds.; Springer: Berlin, Germany, 2009 ; pp. $305-323$.

30. Sarıdemir, M. Predicting the compressive strength of mortars containing metakaolin by artificial neural networks and fuzzy logic. Adv. Eng. Softw. 2009, 40, 920-927. [CrossRef]

31. Nehdi, M.L.; Soliman, A.M. Artificial Intelligence Model for Early-Age Autogenous Shrinkage of Concrete. ACI Mater. J. 2012, $109,353-361$. 
32. Nehdi, M.L.; El Chabib, H.; El Naggar, M.H. Predicting Performance of Self-Compacting Concrete Mixtures Using Artificial Neural Networks. Mater. J. 2001, 98, 394-401.

33. Comité Européen de Normalisation (CEN). EN-1992-1-1: Eurocode 2: Design of Concrete Structures: Part 1-1: General Rules and Rules for Buildings; Comité Européen de Normalisation (CEN): Brussels, Belgium, 2008; p. 259.

34. João Nuno, P.; de Jorge, B.; Carlos, C.; Luís, E. Probabilistic Conversion of the Compressive Strength of Cubes to Cylinders of Natural and Recycled Aggregate Concrete Specimens. Mater. J. 2009, 12, 1-11.

35. Zain, M.F.M.; Abd, S.M. Multiple Regression Model for Compressive Strength Prediction of High Performance Concrete. J. Appl. Sci. 2008, 9, 155-160. [CrossRef]

36. Demuth, H.; Beale, M. Neural Network Toolbox 5, User's Guide; MathWorks Inc.: Natick, MA, USA, 2007.

37. Smith, G.N. Probability and Statistics in Civil Engineering: An Introduction; Collins: London, UK, 1986.

38. Boudali, S.; Abdulsalam, B.; Soliman, A.M.; Ayed, K.; Kerdal, D.E. Green Self-Compacting Sand Concrete Exposed to Sulfate Attack; CSCE Resilient Infrastructure: London, UK, 2016; pp. 1-11.

39. DIN Standards Committee Building and Civil Engineering, European Standard Norme EN. Cement-Part 1: Composition, Specifications and Conformity Criteria for Common Cements 197-1; European Committee for Standardization: Brussels, Belgium, 2000; pp. 1-29.

40. American Society for Testing and Materials (ASTM) C494. Standard Specification for Chemical Admixtures for Concrete; American Society for Testing and Materials (ASTM): West Conshohocken, PA, USA, 2015.

41. ASTM C192. Standard Practice for Making and Curing Concrete Test Specimens in the Laboratory; American Society for Testing and Materials: West Conshohocken, PA, USA, 2012.

42. NF P 18-400 Concretes-Moulds for Cylindrical and Prismatic Test; Association Française de NORmalisation AFNOR: Paris, France, 1981; ISBN 978-2-12-131871-4.

43. ACI Committee 318. Building Code Requirements for Structural Concrete and Commentary; American Concrete Institute: Farmington Hills, MI, USA, 2014; p. 520.

44. Poon, C.; Shui, Z.; Lam, L. Effect of microstructure of ITZ on compressive strength of concrete prepared with recycled aggregates. Constr. Build. Mater. 2004, 18, 461-468. [CrossRef]

45. Boudali, S.; Soliman, A.M.; Abdulsalam, B.; Ayed, K.; Kerdal, D.E.; Poncet, S. Microstructural Properties of the Interfacial Transition Zone and Strength Development of Concrete Incorporating Recycled Concrete Aggregate. Int. J. Civil Envir. Struct. Constr. Archit. Eng. 2017, 11, 966-970.

46. Señas, L.; Priano, C.; Marfil, S. Influence of recycled aggregates on properties of self-consolidating concretes. Constr. Build. Mater. 2016, 113, 498-505. [CrossRef]

47. Gayarre, F.L.; Serna, P.; Cabo, A.D.; López, M.; Ángel, S.; López-Colina, C. Influence of recycled aggregate quality and proportioning criteria on recycled concrete properties. Waste Manag. 2009, 29, 3022-3028. [CrossRef] [PubMed]

48. Sim, J.; Park, C. Compressive strength and resistance to chloride ion penetration and carbonation of recycled aggregate concrete with varying amount of fly ash and fine recycled aggregate. Waste Manag. 2011, 31, 2352-2360. [CrossRef]

49. Yaprak, H.; Aruntas, H.Y.; Demir, I.; Simsek, O. Effects of the fine recycled concrete aggregates on the concrete properties. Int. J. Phys. Sci. 2011, 6, 2455-2461.

50. Fan, C.-C.; Huang, R.; Hwang, H.; Chao, S.-J. Properties of concrete incorporating fine recycled aggregates from crushed concrete wastes. Constr. Build. Mater. 2016, 112, 708-715. [CrossRef]

51. Huda, S.B. Mechanical and Durability Properties of Recycled and Repeated Recycled Coarse Aggregate Concrete. Ph.D. Thesis, University of Britsh Columbia, Vancouver, BC, Canada, 2014.

52. Huda, S.B.; Alam, M.S. Mechanical and Freeze-Thaw Durability Properties of Recycled Aggregate Concrete Made with Recycled Coarse Aggregate. J. Mater. Civ. Eng. 2015, 27, 04015003. [CrossRef]

53. Kapoor, K.; Singh, S.P.; Singh, B. Water Permeation Properties of Self Compacting Concrete Made with Coarse and Fine Recycled Concrete Aggregates. Int. J. Civ. Eng. 2016, 16, 47-56. [CrossRef]

54. Corinaldesi, V. Mechanical and elastic behaviour of concretes made of recycled-concrete coarse aggregates. Constr. Build. Mater. 2010, 24, 1616-1620. [CrossRef]

55. Limbachiya, M.C.; Leelawat, T.; Dhir, R.K. Use of recycled concrete aggregate in high-strength concrete. Mater. Struct. 2000, 33, 574-580. [CrossRef]

56. Buyle-Bodin, F.; Hadjieva-Zaharieva, R. Influence of industrially produced recycled aggregates on flow properties of concrete. Mater. Struct. 2002, 35, 504-509. [CrossRef]

57. Etxeberria, M.; Vázquez, E.; Marí, A.; Barra, M. Influence of amount of recycled coarse aggregates and production process on properties of recycled aggregate concrete. Cem. Concr. Res. 2007, 37, 735-742. [CrossRef]

58. Corinaldesi, V.; Moriconi, G. The role of industrial by-products in self-compacting concrete. Constr. Build. Mater. 2011, 25, 3181-3186. [CrossRef]

59. Etxeberria Larrañaga, M. Experimental Study on Microstructure and Structural Behaviour of Recycled Aggregate Concrete. Ph.D. Thesis, Universitat Politecnica de Catalunya, Barcelona, Spain, 2004. 